\title{
Promising Natural Products in Crop Protection and Food Preservation: Basis, Advances, and Future Prospects
}

\author{
Temitope A. Ogunnupebi $(\mathbb{D}$, Abimbola P. Oluyori $(\mathbb{D}$, Adewumi O. Dada, Oluwole S. Oladeji, \\ Adejumoke A. Inyinbor, and Godshelp O. Egharevba
}

Industrial Chemistry Programme, Department of Physical Sciences, Landmark University, Omu-Aran, Kwara State, Nigeria

Correspondence should be addressed to Abimbola P. Oluyori; oluyori.abimbola@lmu.edu.ng

Received 10 April 2020; Revised 12 June 2020; Accepted 15 June 2020; Published 30 July 2020

Academic Editor: Anshu Alok

Copyright (C) 2020 Temitope A. Ogunnupebi et al. This is an open access article distributed under the Creative Commons Attribution License, which permits unrestricted use, distribution, and reproduction in any medium, provided the original work is properly cited.

\begin{abstract}
The increase in demand for agricultural produce necessitates the continuous search for affordable, ecofriendly, readily available crop protectors, and food preservatives. Historically, the use of various chemicals was employed in controlling plant diseases and to maintain food quality. In the past few decades, several natural product-based alternatives have been discovered and projected as better alternatives to synthetic pesticides and other synthetic agrochemicals. Recent studies focusing on the application of different botanicals in crop protection and food preservation were carefully selected and reviewed. The application of plant extract in the biogenic preparation of nanoparticles was also reviewed. This review confirms that several natural products can be used as a safe replacement for synthetic agrochemicals. Different plant extracts have also served as feed for the synthesis of nanoparticle, which is increasingly applicable in crop protection and food preservation.
\end{abstract}

\section{Introduction}

The ever increasing population of man has continued to fuel the global urge for producing cash and food crops. The recent breakthrough in food production is partly due to the discovery and usage of synthetic agrochemicals and food preservatives, which significantly resolved several issues [1]. The resulting abundance of high-quality agricultural produce has subdued concerns associated with food scarcity in developed nations [2]. However, environmental and health concerns associated with the consumption of these agricultural products massively led to the search for safer and cheaper agrochemicals and food preservatives from natural products.

The innovative approach to enhance global food productivity is achievable through applications of sustainability channels. In advanced countries, agrochemicals are applied not only to preserve foods but also to mitigate pest invasion leading to unbroken food supply $[3,4]$. In recent times, pesticides are observed to interact with the plant genome and the ecosystem. They eventually get metabolized in organisms' tissues leaving disastrous end-products $[5,6]$. These end-products (or metabolites) are adjudged to pose serious threats to target organisms, man, and the ecosystem [7]. Although consumption of fruits and vegetables is encouraged by Food and Agriculture Organization (FAO) and World Health Organization (WHO), however, the uptake of pesticide residues in most farm products (including vegetables and fruits) creates daunting aftermaths [8]. FAO and WHO have published recommended limits of organophosphates, carbamates, and organochlorine pesticides both in food and cash produce. Table 1 presents the maximum residue limits of various pesticides in fruit and vegetable.

The table was developed from FAO and WHO data $[9,10]$.

The intake of organophosphate residue in food was found to cause antiandrogenic effects and interfere with semen production, ejaculation, and total sperm count in male organisms [11-13]. Pyrethroid pesticides such as trans3-(2, 2-dichlorovinyl)-1-methylcyclopropane-1, 2-dicarboxylic acid and 3-pherooxybenzoic acid were linked to abnormal morphology and low sperm motility $[14,15]$. 
TABle 1: Maximum residues' limits of pesticides in fruits and vegetables.

\begin{tabular}{|c|c|c|c|c|c|c|c|}
\hline \multicolumn{8}{|c|}{ Maximum residue limit (MRL) in $\mathrm{mg} / \mathrm{kg}$} \\
\hline \multirow{2}{*}{$\begin{array}{l}\text { Class of pesticides } \\
\text { Examples }\end{array}$} & \multicolumn{2}{|c|}{ Carbamate } & \multicolumn{3}{|c|}{ Dithiocarbamates } & \multicolumn{2}{|c|}{ Pyrethroid } \\
\hline & Benomyl & Carbaryl & Carbosulfan & Mancozebthiram & Cypermethrin & Deltamethrin & Fenvalerate \\
\hline Sweet corn & & 1.0 & & & 0.05 & & 0.1 \\
\hline Cucumber & & 3.0 & 0.5 & 2.0 & & & \\
\hline Watermelon & & 1.0 & 0.2 & 1.0 & & & \\
\hline Brassica vegetables & & 1.0 & 0.5 & & 1.0 & 0.1 & 2.0 \\
\hline Peppers chili & 2.0 & 0.5 & 0.5 & 2.0 & 2.0 & 0.1 & \\
\hline Mango & 2.0 & 1.0 & & 2.0 & 0.7 & 0.2 & 1.5 \\
\hline Potato & & 0.2 & 0.05 & 0.2 & & & 0.05 \\
\hline Citrus fruits & 3.0 & 7.0 & 0.1 & 2.0 & 0.3 & & \\
\hline Grapes & 3.0 & 5.0 & & 5.0 & 0.5 & & \\
\hline Spring onion & 0.5 & & & & & 0.3 & 2.0 \\
\hline Tomato & 3.0 & & & 10.0 & 0.2 & 0.1 & \\
\hline Shallot & 2.0 & & 0.5 & 0.5 & 0.1 & 0.05 & \\
\hline Onion, bulb & & & & 0.5 & 0.01 & & \\
\hline Okra & & & 0.5 & 0.2 & 0.5 & & \\
\hline Egg plant & & & 0.03 & 0.2 & 0.03 & 2.0 & \\
\hline Kale & & & & 15.0 & & & \\
\hline Pumpkins & & & & 0.2 & & 2.0 & \\
\hline Cabbage & & & & & & & 3.0 \\
\hline Papaya & & & & & 0.5 & & \\
\hline Class of pesticides & \multicolumn{3}{|c|}{ Organophosphate } & Organochlorine & Bipyridyliums & \multicolumn{2}{|c|}{ Triazine } \\
\hline Examples & Chlorpyrifos & Dimethoate & Malathion & DDD & Paraquat & Atrazine & Ametryn \\
\hline Cabbages & 1.0 & & 8.0 & 0.02 & 0.07 & & \\
\hline Sweet corn & & & 0.02 & & & 0.1 & \\
\hline Spinach & 0.5 & & & 0.2 & 0.07 & & \\
\hline Banana & 2.0 & & & & & & \\
\hline Okra & 0.5 & & & & & & \\
\hline Cauliflower & & 0.2 & 0.5 & & & & \\
\hline Spring onion & & & 5.0 & & 0.05 & & \\
\hline Broccoli & & & 5.0 & & 0.07 & & \\
\hline Kale & & & 1.0 & & 0.07 & & \\
\hline Peppers chili & 3.0 & & 0.1 & & & & \\
\hline Tomato & & 2.0 & 0.5 & & 0.05 & & \\
\hline Citrus fruits & & 5.0 & 7.0 & & 0.02 & & \\
\hline Shallot & 0.2 & 0.5 & 1.0 & & & & \\
\hline Onion, bulb & 0.2 & 0.5 & 1.0 & & 0.05 & & \\
\hline Potatoes & 3.0 & & & & 0.05 & & \\
\hline Cucumber & 1.0 & & & & 0.02 & & \\
\hline Pineapple & & & & & & 0.1 & 0.1 \\
\hline
\end{tabular}

Recently, health defects such as nausea, headache, endocrine disruption, cancer, oligospermia, and azoospermia have been reported from the intake of pesticide metabolites in food $[8,16]$. There have been major concerns about acts protecting the consumers of agricultural products in Africa. Certain farmers and marketers do not comply with these rules because of their selfish interest, while the improper usage of pesticides by others has been linked to a lack of awareness of the right adequate dose to be administered [3].

Crop protection and food preservation are indispensable entities in global food sustainability. Several methods of preservation have effectively prevented food spoilage caused by insect infestation, climatic conditions, and microbial attacks [17]. However, studies revealed vast health issues relating to applications of synthetic pesticides and preservatives $[6,18]$. This spurred the search for safe and economical materials without harmful or detrimental effects to the health of consumers and the environment at large. Several natural preservatives and pesticides have been formulated and applied in food, pharmaceutical, and agrochemical industries $[1,19,20]$. In a broad sense, plant metabolites constitute the basic unit of life, protect plants from ultraviolet radiation, attract insect pollinator, promote hormone production, and enhance plants' survival. Phytochemicals such as alkaloids, phenylpropanoids, polyketides, terpenoids, carbohydrates, amino acids, lipids, and nucleic acids are essential materials in the production of several pesticides, herbicides, insecticides, and virucides [21-23]. This review is focused on appraisals of natural agrochemicals with promising protection and preservative potentials on crop and food products. It also explores the basis, advances, 
and potential prospects of natural preservatives and pesticides. This will enlighten farmers, marketers, government agents, and stakeholders on the potential threats accompanying indiscriminate usage of pesticides and food preservatives, thus promoting good health and environmental sustainability.

\section{Crop Protection: An Overview of Current Methods}

In the past two decades, the production and distribution of crop and food products have been severely affected due to the invasion of drug resistance microbes, pests, and other external influences [24]. Particularly, pests have significantly affected the socioeconomic aspect of most developing countries by causing depletion and extinction of most crop species. The impact of pests on agriculture is evidenced in the reduction of crop yield, production capacity, plant density, and plant development [25]. In advanced countries, several measures have been designed to counter pests' attacks on crops and crop products. The most efficient method is the use of pesticides, which are classified into insecticides, fungicides, herbicides, virucides, bactericides, nematicides, molluscicides, and rodenticides based on the target species [4]. Biopesticides, which include naturally occurring pesticides in plants and genetically modified plants, have continued to gain much attention $[6,26]$. Research has revealed that pesticides are vital in the protection of plants from pest invasion before the product gets to the final consumers [27]. This review focuses on insecticides, herbicides, fungicides, and virucides [3, 25]. Majorly, target organisms come in contact with the pesticides when applied directly by spraying on plants or indirectly. Certain applications of pesticides cause physical and biological damage to the target organisms by destroying key organs and interfering with some life processes such as photosynthesis, cell mitosis, and reproduction $[6,28,29]$.

\subsection{Current Methods of Crop Protection}

2.1.1. Herbicides. Over the years, herbicides have been seen as an agent, which control the growth of unwanted plants in a sustainable way. Synthetic herbicides are widely engaged and are made available to farmers at cheaper prices $[1,30,31]$. Based on the mode of interaction, there are selective or nonselective herbicides. Nonselective herbicides affect a wide variety of plants alongside the target weed and are engaged in clearing large areas such as construction sites and fallow grounds, while selective herbicides work majorly by restricting the growth of targeted plants [31]. Certain herbicides are taken up through foliage, and they either function as inhibitors, disruptors, or regulators of various biosynthetic pathways [31, 32]. Examples of synthetic herbicides are glyphosate, imazapyr, hexazinone, paraquat, and picloram [30,33], while examples of organic herbicides include corn gluten meal, D-limonene citrus oil (plantbased), and monocerin (fungi-based) [1].
2.1.2. Fungicides. Fungal growth (spores), which affect the growth and well-being of plants, can be successfully inhibited by the utilization of fungicides [29]. Based on their mode of activity, fungicides are categorized into three types: systematic, contact, and translaminar fungicides [34]. Systematic fungicides are redistributed by the xylem vessels after been absorbed, thereby blocking mitosis and cell division. Contact fungicides, however, works only on places sprayed and are not absorbed by plant tissues [34, 35]. Translaminar fungicides help in even distribution of fungicides from the upper parts of the plants to the lower parts [36]. Synthetic fungicides such as azoxystrobin, prochloraz, or thirame are mostly employed in crop protection, while examples of natural fungicides include rosemary oil, tea tree oil, and jojoba oil among many others [37-39].

2.1.3. Insecticides. Insecticides are applied to depopulate or eliminate the pests, which cause qualitative and quantitative damages to plants and farm produce $[40,41]$. Insecticides have been successfully applied to increase mortality rates of insects, while ovicides and larvicides have successfully targeted the insect eggs and larvae stages, respectively [42, 43]. Several insecticides are utilized in agriculture, medicine, and households to prevent the activities of insects. Chemical compounds such as carbamates, nicotinoids organochlorine, organophosphate, and pyrethroids are the major constituents of insecticides [27, 41]. The two major classes of insecticides are systematic and contact insecticides [44]. Systematic insecticides are applied to plants (which the insects will consume and die), while contact insecticides are applied directly to the insect. Upon contact, the insect dies [44]. The mechanisms by which insecticides exert their activity have been investigated. Several chemical classes of insecticides act as either inhibitors, agonists, antagonists, regulators, or neurotoxicants based on the target site in the nervous system such as acetylcholine receptors, acetylcholinesterase, and voltage-gated sodium channels across the nerve membrane $[41,45]$. Insecticides can be categorized as synthetic (inorganic and organic) and natural insecticides. Inorganic insecticides lack carbon in their structure and contain metals, e.g., copper sulfate, ferrous sulfate, and copper, while organic insecticides are carbon-containing compounds such as captan, carbamate, and glyphosate. Natural insecticides include nicotine and pyrethrum amongst others $[1,43,45,46]$.

2.1.4. Virucides. Viruses are infectious agents that can only replicate in living cells of a particular host such as plants, and they are linked to several damages and wastage of crop produce $[47,48]$. In the treatment of viral diseases, virucides and antiviral agents have been effectively and successfully utilized for this effect. Virucides are known to completely eradicate viruses, while antiviral agents hinder the replication of viruses in cells and stop the transfer of viruses. Antiviral agents do not destroy the virus [47, 49]. Furthermore, the antiviral agents come in contact with the plant through foliar, get absorbed by the stomata, and move into the tissues of the plant. The resulting outcome is the 
inhibition of the activity of the viral nucleic acids (DNA and RNA), which causes replication of viral cells $[47,49,50]$. Examples of synthetic antiviral agents are bavistin, benlate, and ribavirin, while antofine, duflin, glucan, and ningnanmycin are examples of natural antiviral agents commonly used $[47,50,51]$.

\subsubsection{Other Methods of Pest Management. Other methods} include the use of natural predators or parasites such as lacewings, lady beetles, wasps, and hoverfly larvae, which feeds on a wide range of insects such as aphids, scale insects, spider mites, whiteflies, and many others [52]. Microbes such as Trichoderma spp., which help in protecting and keeping the plants healthy can be introduced [53]. Physical barriers such as scarecrows, traps, nets, or nearness to farmstead contribute to terrifying birds and scaring animals away [54]. Cover crops such as red clover, common vetch, daikon radish, or sweet clover are also utilized in controlling weed and help to fix nitrogen in the soil $[55,56]$. Interestingly, the advent of cross-breeding and modification of genes in some plants has been employed to boost their disease/insect resistance traits [57, 58], unique dietary combinations, high protein content, resistance to herbicides [59], and drought and saline tolerance [60].

\subsection{Negative Effects of Current Methods in Crop Protection.} Inappropriate use of synthetic pesticides has led to pollution of a diverse kind in the environment, which is detrimental to man and his environment. The chemicals are applied directly to crops to protect them from attacks by insects, and this has been known to cause unsolicited problems [32, 46, 61]. Extensive and uninformed use of pesticides available in the market often leads to resistance from pests. The use of synthetic pesticides has helped greatly in crop protection. However, after a while, they accumulate and contaminate the environment moving from one medium to another. They particularly affect drinking water or penetrate the food chain $[3,25,46]$. Certain pesticides that are used for postharvest preservation are expected to disintegrate into nonharmful products after some time. However, these chemicals are not allowed to disintegrate before crop products are sold to consumers, and this has caused food poisoning for some families [62]. The use of toxic pesticides is still prominent, as farmers continue to make use of banned products, which engender environmental challenges and affect the well-being of farmers. Farmers who are exposed to arsenic poisoning are potentially at risk of occupational skin cancer and Bowen's disease [63]. The use of protective suits by farmers is on a decline, and farmers are stricken by various diseases as a result $[63,64]$. Several reports covered the effects of pesticides on male hormonal function, while few have considered its effects on female hormonal function [61]. Certain studies have been able to ascertain the correlation between the menstrual cycle and pesticide exposure. Some irregularities such as long menstrual cycles, intermenstrual bleeding, and missed periods have $60-100 \%$ chances of occurring in people with pesticide exposure compared with women not exposed to pesticides $[65,66]$.
The environmental effects of pesticides have been studied and found to be caused by the percolation of pesticide constituents into water bodies via mechanical media such as wind or rain. Over time, the accumulation of pesticide residue in water bodies can threaten the growth, survival, and reproduction of aquatic organisms $[3,27,46]$. Aquatic organisms interact with pesticides by direct absorption through the skin, through the gills, and the mouth. Unsuspecting consumers such as pregnant or nursing mothers are prone to health issues after consuming contaminated fishes [67]. Even though pesticides disintegrate through processes such as photodecomposition, thermal degradation, and microbial decay, the processes are slow. The resulting exposure of aquatic animals to pesticides such as aldrin, dieldrin, DDT, malathion, endosulfan, dichlorvos, pyrethroid, methyl parathion, and chlordane were reported to cause an increased hemoglobin content [68], endocrine/ hormonal imbalance, histopathological changes in the liver and gills, hematopoietic tissue, genetic defect, hyperactivity [69], hyperstimulation [70], and impairment of metabolism in fish, vertebral deformities, and behavioral disorder. Specifically, these exposure results in blindness, loss of appetite, induced sterility, decrease in fertility, interference with natural defense mechanisms, and eventually death [71-73]. The life cycle of salmon is affected by the exposure to specific pesticides that alter their ability to swim, get food, maintain a position in the river, avoid predators, and define territories. Furthermore, the transition state is impaired in salmonids, while spawning is delayed in adult salmon. There is also a change in behavior, blockage of sex hormones, and poor bone development [74]. Also, the effect of pesticides on soil microorganisms has been reported. It was observed that some mycoflora were inhibited by the addition of fungicides. However, the soil mycoflora soon overcame the effect of the fungicides [39]. Another important use of herbicides is the control of plants that block pipelines in houses and industries. Herbicides that have been used to control the unwanted blockage of sewer pipelines by cottonwood tree roots include triclopyr $(5.22 \mathrm{mg} / \mathrm{L})$, penoxsulam $(0.83 \mathrm{mg} /$ $\mathrm{L})$, and dithiopyr $(1.15 \mathrm{mg} / \mathrm{L})$. Although a high concentration of these herbicides inhibit nitrification in wastewater treatment and slow down the removal of organic carbon in activated sludge, the use of highly diluted herbicides does not lead to such an unwanted activity [75]. Besides, it has been found that some herbicides stay longer in the soil and affect the growth of other crops on rotation [76].

\subsubsection{Challenges with Other Methods of Pest Management.}

Different methods have been engaged in the control of the pest attack. However, there are some setbacks associated with their uses. For example, making use of natural predators does not ascertain complete eradication of the target pest, and the absence of target pest when natural predators are introduced can cause damages to crops. Likewise, the introduction of these natural predators can be time-consuming, especially if the farm is large [77]. Cover crops have been successfully applied to prevent loss of water from the soil. However, during winter, it causes reduction in soil 
water [55]. Genetically modified (GM) species have provided a solution to several challenges related to crop protection over the years. However, whenever these GM plants are found in unwanted places on the farm, removing them becomes a challenge since they are herbicide-resistant $[78,79]$. Even though scarecrows have been used on the farm to chase birds away, they are not efficient, and over time the bird gets used to the still images [54]. A summary of the negative effects of the current methods used in crop protection is shown in Table 2.

2.3. Natural Products in Crop Protection. Several studies have examined the application and efficacy of plant extracts in the fight against various diseases affecting plants. Solvent extracts from various plants have exhibited great potential in combating weeds invasion and microbial attacks.

2.3.1. Natural Products as Herbicides. Weeds are becoming resistant to conventional herbicides such as glyphosate, and natural products are serving as good alternatives [85]. Plants and microorganisms are major sources of secondary metabolites, which have found diverse application in agriculture. Plants that release chemical substances that affect the growth, nutrient uptake, and reproduction of other organisms are said to be allelopathic. Studies have shown that plants with the strong allelopathic activity are used in weed control. In recent times, crude extracts from different plant parts have been used effectively to hinder weed germination and growth [86]. Melaleuca cajuputi extract contains active compounds such as caryophyllene, eugenin, humulene, which are responsible for its medicinal properties and herbicidal potential [87]. Root extracts from Mikania micrantha afforded four novel thymol derivatives, which were discovered to have allelopathic properties [88]. Nine active compounds were discovered from the ethanol extracts of five Amaranthus species leaf. Amongst these, coumarin and saponins were responsible for the observed allelopathic effect against lettuce [89]. Bioachanin A, an important isoflavone, exhibited a phytotoxic effect against both dicotyledon and monocotyledon weed species such as Amaranthus caudaus L. and Echinochloa crusgalli L. species. Interestingly, the degradation product of biochanin A is phytotoxic to the same weed species [90]. Similarly, two furanocoumarins (chalepin and chalepensin) were isolated from root and aerial parts of Ruta graveolens and taproots of Hortia oreadica. They effectively inhibited the growth of Allium cepa, Lepidium sativum, and Lycopersicon esculentum, thus showing greater impact than those of synthetic herbicides [91]. Furthermore, aqueous extracts from Nerium oleander L., Olea europaea L., and Ricinus communis L. leaves and synthetic herbicides (tibenuron) were applied to inhibit the growth of Cyperus rotundus L. [32]. Worth of note is the fact that $N$. oleander extracts gave the highest inhibitory effect compared to the other two extracts and the synthetic herbicide. Although the active compounds in the extracts were not isolated/characterized, phytochemicals such as phenolic compounds, flavonoids, terpenoids, and alkaloids were generally found to be responsible for the allelopathic activity of the extracts [32].

Asides from plants, several organisms such as bacteria, fungi, and viruses have also been known to produce phytotoxic substances. For instance, certain microorganisms have been established as sources of bioactive secondary metabolites. An example is the new strain of Lasiodiplodia pseudotheobromae, from which the bioherbicide, mellein, was extracted and chromatographically purified. Mellein exhibited a notable activity on Setaria italic, Cyanoclon dactylon, Axonopus compressus, and Valerianaceae [92]. Similarly, Pseudomonas aeruginosa produced a bioherbicide (2-(hydroxymethyl) phenol), which inhibited the growth of pigweed and sorghum [93], while two herbicidal compounds were isolated from a strain of Streptomyces and were successfully used to inhibit the growth of Digitaria sanguinalis and Sorghum bicolor among other grasses [94]. Furthermore, a fungal strain from Trichoderma polysporum was employed in inhibiting the growth of Pisum sativum and Vicia faba L. [95], while Trichoderma koningiopsis caused 60\% foliar damage on Euphorbia heterophylla (Mexican fire plant) [96]. A worthy note is that $1 \mathrm{D}$ and $2 \mathrm{D}$ NMR as well as mass spectrometry were employed in the characterization of most of these phytotoxic compounds. Structures of these herbicidal compounds are shown in Figure 1.

2.3.2. Natural Products as Fungicides. Several plant extracts have been successfully employed as fungicides. Examples include Azadirachta indica leaf extract [97], peels of Ipomoea batatas Lam [98], Curcuma longa leaves [37], C. papaya leaves [38], and thyme and lemongrass extract [99]. The activity of Azadirachta indica leaf extract can be attributed to the presence of compounds such as dibutyl phthalate, phytol, nonanoic acid, tritriacontane, and 1,2benzenedicarboxylic acid in the crude extracts [97]; Similarly, three compounds namely stigmasterol, 3 -friedelanol, and urs-13(18)-ene-3 $\beta$-yl acetate were identified in the peels of Ipomoea batatas Lam. with a reasonable activity against the growth of Sporothrix schenckii and Trichophyton metagrophytes fungi [98]. Thyme and lemongrass extract successfully reduced sheath blight disease in rice by attacking $R$. solani, thereby enhancing crop growth and yield of grains [99]. These activities are a result of the essential oils, saponins, tannins, flavonoids, and other phenolic compounds that were present in the extracts $[100,101]$. Furthermore, extracts from Curcuma longa leaves have been found to possess impressive minimum inhibitory concentrations of $6.25 \mu \mathrm{g} / \mathrm{ml}$ against Aspergillus fumigatus and $12.5 \mu \mathrm{g} / \mathrm{ml}$ against helminthosporium spp. [37]. Furthermore, a soilborne disease, which is also known as pink root disease (initiated by a fungus-Pyrenochaeta terrestris (Hansen)), constitutes a problem for onions in the nursery. However, extracts from A. indica and C. papaya leaves were compared well with synthetic fungicides in the inhibition of this fungus disease. Therefore, A. indica and C. papaya leaves can be engaged as a cheap, readily available, and environmentally friendly alternative in the antifungal therapy [38]. 
TABLE 2: Negative effects of current methods of crop protection.

\begin{tabular}{|c|c|c|c|}
\hline Methods & Examples & Disadvantages & References \\
\hline \multirow[t]{2}{*}{ Herbicides } & $\begin{array}{l}\text { Dimethylarsinic acid diuron, } \\
\text { imazapyr, and picloram }\end{array}$ & $\begin{array}{c}\text { Dizziness, headache, vomiting, fall in blood pressure, convulsions, } \\
\text { and general paralysis }\end{array}$ & {$[62,80]$} \\
\hline & & Cancer & [33] \\
\hline Fungicides & $\begin{array}{l}\text { Mancozeb, malathion thirame, } \\
\text { and fenarimol }\end{array}$ & $\begin{array}{l}\text { Inhibition of hormone synthesis, developmental defects, menstrual } \\
\text { cycle irregularities, impaired fertility, and spontaneous abortion/ } \\
\text { stillbirths }\end{array}$ & {$[61,81,82]$} \\
\hline \multirow{4}{*}{ Insecticides } & Spinetoram & Minimal or mild eye irritation & [83] \\
\hline & Diazinon & Lymphoma & [44] \\
\hline & Aldrin & Liver diseases and lung cancer & {$[54]$} \\
\hline & DDT & $\begin{array}{c}\text { Chronic liver damage, reproductive disorders, cytogenic effects, and } \\
\text { breast cancer }\end{array}$ & {$[61]$} \\
\hline $\begin{array}{l}\text { Genetically } \\
\text { modified species }\end{array}$ & GM maize and soybean & $\begin{array}{l}\text { Higher level of severe inflammation in stomach and lower glucose } \\
\text { levels }\end{array}$ & {$[78,79,84]$} \\
\hline Use of cover crops & $\begin{array}{l}\text { Common vetch, daikon radish, } \\
\text { and sweet clover }\end{array}$ & Soil water depletion & {$[55]$} \\
\hline Natural predators & $\begin{array}{l}\text { Lacewings, lady beetles, and } \\
\text { trichodrema }\end{array}$ & $\begin{array}{c}\text { The introduction of predators at the wrong time causes more } \\
\text { damage to the plants }\end{array}$ & {$[77]$} \\
\hline Use of scare crows & Mannequin or decoy & Not always effective in scaring birds and animals away & [54] \\
\hline
\end{tabular}

The direct application of pure organic compounds has similarly been reported. Five phenolic compounds namely alkylresorcinols (AR), ferulic acid, quercetin, phlorizin, and resveratrol were directly used against the phytopathogenic fungi Botrytis cinerea. Ferulic acid was most effective against several fungal isolates and resistant strain of $B$. cinerea [102]. Another study successfully used lauric acid to eliminate Rhizoctonia solani, Pythium ultimum, and Blumeria graminis growth on barley seedlings [103]. Interestingly, these emerging natural products are getting commercialized. An example is a product called "Plant tonic," which contains alfalfa, humic acid, kelp, and vitamin $\mathrm{B}_{1}$. This product has been used to inhibit mycelial growth and conidial germination of rice blast disease [104].

In the same vein, certain microbes have been found to produce secondary metabolites that have been successfully applied in crop protection. For instance, alteramide B, which has a broad spectrum against phytopathogenic fungi such as Alternaria alternata, Colletotrichum gloeosporioid, Magnaporthe oryzae, and Valsa ambiens, is an active component in Lysobacter enzymogenes [105]. Similarly, a novel strain of bacteria such as Bacillus velezensis has been found useful in the inhibition of Verticillium dahliae, soilborne fungi that affect tomatoes [106] and olives [107]. The antifungal compounds produced by this bacterium include tetradecane, benzaldehyde, and 1-decene amongst many others [106]. Likewise, Ochrobactrum intermedium was used in the treatment of Colletotrichum falcatum, which is responsible for red rot in sugarcane [108]. Also, a novel strain of fungi such as Trichoderma erinaceum was applied in boosting the growth of rice crop and inhibiting the growth of $R h i$ zoctonia solani, Sclerotium oryzae, and Sclerotium rolfsii [109]. Liquid fermentation of brown sugar containing Bacillus megaterium has also been employed in controlling Alternaria japonica, which affects broccoli [110]. Relevant structures of some fungicidal compounds are shown in Figure 2.
2.3.3. Natural Products as Insecticides. In the search for safe, cheap, and sustainable means to control insect infestation, some selected botanicals have been successfully investigated. Crude extracts from different plant parts have displayed notable insecticidal properties. These include Carica papaya seed extract [111], polar and nonpolar extracts of seeds, peels, and pulp of Persea americana Mill [42], stem and leaf extract of Clausena lenis [112], Callistemon citrinus leaf extract [113], ethanolic extract of Annona mucosa seeds [114], citrus essential oil [115], Azadirachta indica seeds, Phytolacca dodecandra seeds, and Schinnus molle seeds [43]. The active constituents in some of these extracts with insecticidal value are not hidden. The phytochemicals in these extracts are directly responsible for observed activities, and their mechanisms of action have been investigated. The neem tree has several products obtainable from its leaf, bark, and seed extracts [116, 117]. In particular, neem seeds contain azadirachtin as its major component. Azadirachtin whose insecticidal property has been well established operates by interfering with feeding, growth, synthesis, and distribution of molting hormones (ecdysteroids) leading to sterility in adult female insects and incomplete molting in the young insects $[118,119]$. This compound is also effective against aphids, beetles, borers, caterpillars, whiteflies, mealy bugs, and weevils and considered as mild against vertebrates or beneficial insects such as ladybugs, bees, and spider $[118,120]$. The wide range of activity observed in azadirachtin led to the various brand of organic insecticides (Agroneem, Azatrol EC, and Ecozin), which have emerged from the neem tree [118]. Similarly, ethanolic extract from A. mucosa seeds owes its insecticidal activity to acetogenins, which are potent against arthropods. Acetogenins exert their action by inhibiting the enzyme of the cellular plasma membrane and mitochondrial electron transport systems of target arthropods [114].

Another example is C. papaya seed extract, which contains an active component "Papain" [111]. This extract has been reported to be toxic against mustard aphid [121], 
<smiles>C[C@@H]1Cc2cccc(O)c2C(=O)O1</smiles>

Mellein<smiles>O=c1ccc2ccccc2o1</smiles>

Coumarin<smiles>COc1cc(CCC(=O)OCC(O)(CO)c2ccc(CO)cc2O)ccc1O</smiles>

7, 8, 10-trithydroxy-9-E-feruloyloxythymol

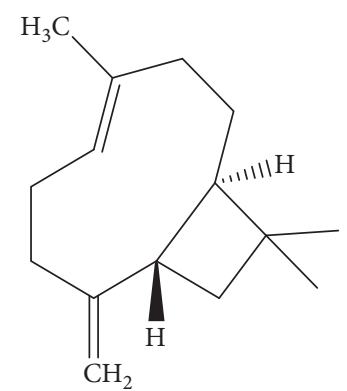

Caryophyllene<smiles>C=CC(C)(C)c1cc2cc3ccoc3cc2oc1=O</smiles>

Chalepensin<smiles>Cc1ccc(C(O)(CO)COC(=O)c2ccccc2)c(O)c1</smiles>

8, 10-dihydroxy-9-benzoyloxythymol<smiles>COc1cc(O)c2c(=O)cc(C)oc2c1</smiles>

Eugenin<smiles>C=CC(C)(C)c1cc2cc3c(cc2oc1=O)O[C@H](C(C)(C)O)C3</smiles>

Chalepin<smiles>COc1ccc(-c2coc3cc(O)cc(O)c3c2=O)cc1</smiles>

Biochanin A<smiles>OCc1ccc(C(O)(CO)CO)c(O)c1</smiles>

7, 8, 9, 10-tetrahydroxythymol

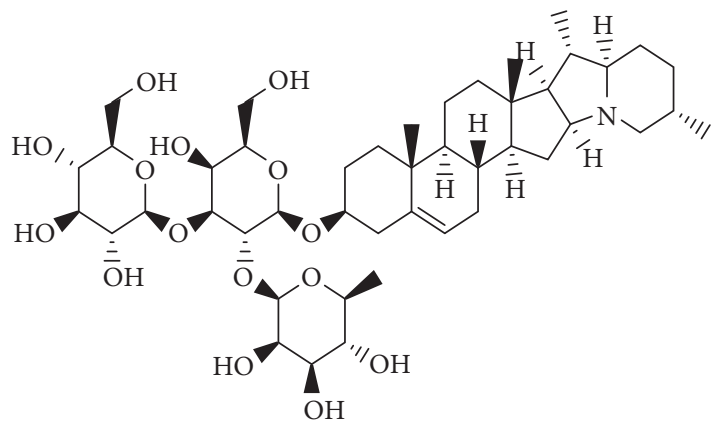

Solanine<smiles>Cc1ccc(C(CO)COC(=O)C(C)C)c(O)c1</smiles>

9-isoobutyryloxy-10-hydrothymol

FIGURE 1: Relevant natural herbicidal molecules.

Sitophilus zeamai [122], cotton aphid, flea beetle, spotted bollworm, and whitefly [123]. Furanocoumarins were identified in C. lenis extract, which possesses insecticidal [112], phytotoxic [91], and antiproliferative [124] properties. Similarly, the active ingredient in citrus essential oil, "Dlimonene", increased the mortality rate of the three species of vineyard mealybugs [115], while bis(2-ethylhexyl) benzene-1, 2-di-carboxylate in ethyl acetate fraction of the Tetraena mongolica stem had a strong larvicidal activity on Pieris rapae larvae (cabbage white) [125]. Studies showed that bruchid-resistant cowpea cultivar powders were successfully used to protect harvested cowpea seeds from insects such as Callosobruchus maculatus [126]. Generally, polar and nonpolar extracts from C. citrinus leaves and $P$. americana fruits owe their antibacterial, antimalarial, antidiabetic, anti-inflammatory, antiviral, anticancer, antiasthma, antifungal, larvicidal, and insecticidal activity to phytochemicals such as alkaloids, flavonoids, tannins, triterpenoids, saponins, polyphenolic (catechins and trans-3O-caffeoylquinic acid), and unsaturated steroids $[42,113,127,128]$. Furthermore, aqueous seed extracts from $A$. indica, S. molle, and P. dodecandra were most active against fall armyworm (FAW) larvae of maize [43]. Most synthetic insecticides have developed resistance to FAW, 
<smiles>Oc1ccc(/C=C/c2cc(O)cc(O)c2)cc1</smiles><smiles>CCCCCCCCCCCC(=O)O</smiles>

Lauric acid<smiles>CCCCCC/C=C\CCCCCCCc1cc(O)cc(O)c1</smiles>

Bilobol

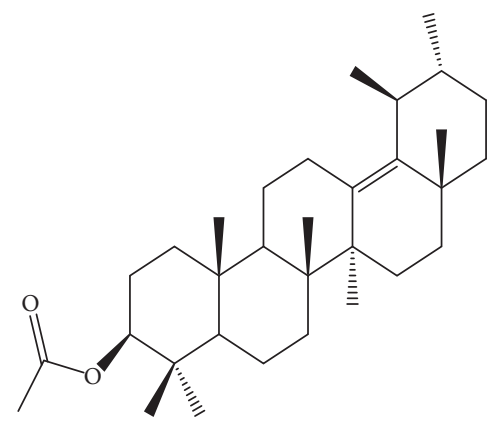

Urs-13 (18)-ene-3B-yl acetate<smiles>O=c1c(O)c(-c2ccc(O)c(O)c2)oc2cc(O)cc(O)c12</smiles><smiles>CCCCCCCCC(=O)O</smiles>

Nonanoic acid<smiles>O=C(CCc1ccc(O)cc1)c1c(O)cc(O)cc1OC1OC(O)C(O)C(O)CC1(O)CO</smiles>

Phlorizin<smiles>COc1cc(/C=C/C(=O)O)ccc1O</smiles>

Ferulic acid<smiles>CC(=CCO)CCCC(C)CCCC(C)CCCC(C)C</smiles>

Phytol<smiles>CCCCOC(=O)c1ccccc1C(=O)OCCCC</smiles>

Dibutyl phthalate<smiles>C[C@H]1[C@@H](O)CCC2[C@@]3(C)CC[C@]4(C)C5CC(C)(C)CC[C@]5(C)CC[C@]4(C)C3CC[C@]21C</smiles>

3 -friedelanol<smiles>CCCCCCCC(=O)C=CC=CC1CC2CC(CC)C(C)C2C1C(O)C=CC=CC(=O)C1=C(O)C(C(O)CCC)NC1=O</smiles>

Alteramide B

Figure 2: Relevant natural fungicidal molecules.

which necessitated the search for natural botanicals [129]. In summary, the use of seed extracts is more prominent alongside the use of other plant parts for their insecticidal activity. However, this is a subject for future investigation.

Furthermore, certain microbes have also demonstrated insecticidal potential in recent times. An emulsifiable concentrate of fungus Metarhizium rileyi was successfully used to control the infestation of maize by fall armyworm [130]. Similarly, entomopathogenic fungus, Beauveria bassiana, was able to significantly increase the mortality rate of both nymphs and adult forms of tomato/potato psyllid. If not controlled, this tomato/potato psyllid affects bell pepper, eggplant, potato, and tomato, while secondary metabolites such as oosporeins, bassiacridin, and bassianin were responsible for the high mortality rate [131, 132]. In the same vein, methanol extracts from Cladosporium cladosporioides and Purpureocillium lilacinum have been used to effectively control the population growth of Aphis gossypii and cotton aphid. The major constituents in the extracts were identified as linoleic acid and palmitic acid [133]. Another example is Metarhizium anisopliae, which caused 98\% and 87.1\% mortality effect in two-spotted spider mites (Tetranychus urticae and Tetranychus cinnabarinus), respectively [134]. Entomopathogenic bacterium, Bacillus thuringiensis, exhibited insecticidal activity against Plutella xylostella larvae (diamondback moth) and also protects Brassica campestris (field mustard) from sclerotiniose [135]. Relevant structures of some insecticidal compounds are shown in Figure 3.

2.3.4. Natural Products as Virucides. Several studies have shown that there are thousands of plant viruses, but the available treatment is not sufficient in eradicating these infections. This has led to a continuous search for sustainable alternatives. Interestingly, some plants naturally resist virus 
<smiles>NCCC(=O)NC(Cc1cnc[nH]1)C(=O)O</smiles>

Papain<smiles>Oc1cc(O)c2c(c1)O[C@H](c1ccc(O)c(O)c1)[C@H](O)C2</smiles>

Catechin<smiles>CC1=C(O)C(=O)C(C2=C(O)C(=O)C(C)=C(O)C2=O)=C(O)C1=O</smiles>

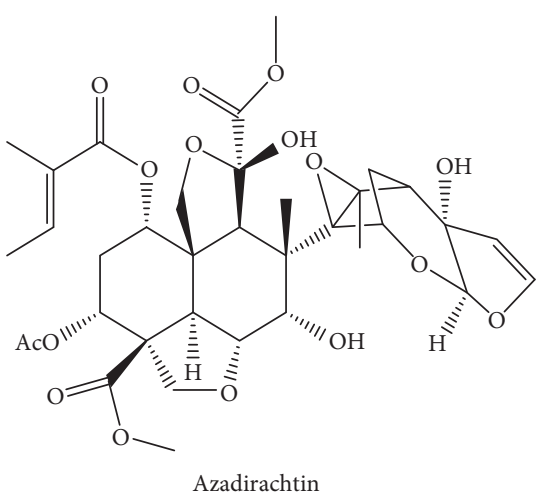<smiles>O=C(/C=C/c1ccc(O)c(O)c1)O[C@@H]1C[C@@](O)(C(=O)O)C[C@H](O)[C@H]1O</smiles>

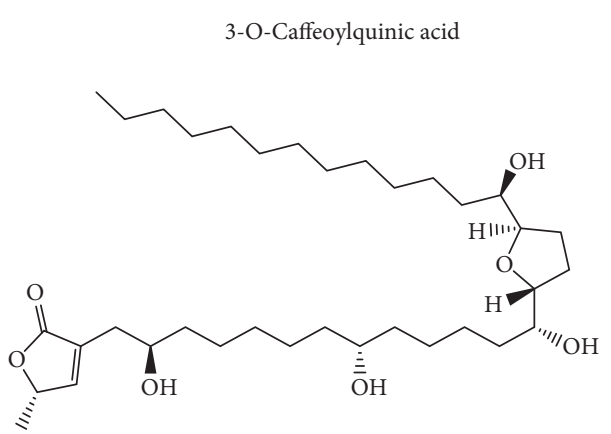

Acetogenin
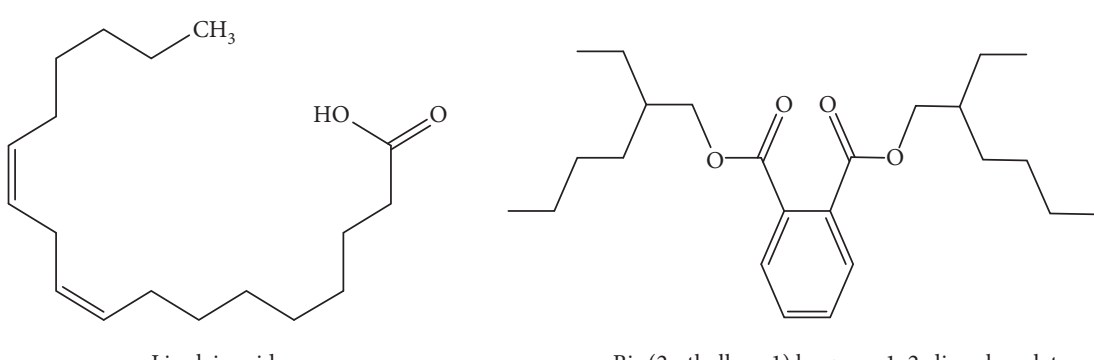

Bis (2-ethylhexy1) benzene-1, 2-di-carboxylate

Figure 3: Natural insecticidal molecules.

replication in their cells, while some natural extracts resist virus replication when applied to other plants [47]. A rich review has been carried out on the use of antiviral agents from natural sources against the tobacco mosaic virus (TMV), which is common among tobacco, cucumber, pepper, and ornamentals [51]. Some of these botanicals include Picrasma quassioides [136], Glycyrrhiza glabra L. [137], Arundina graminifolia [138], Tithonia diversifolia [139], Cephalotaxus sinensis [140], Actinidia chinensis [141], and prickly pear [142]. Similarly, Salix alba [48], Tanacetum vulgare [143], C. sinensis [140], prickly pear [144], and A. chinensis [141] showed an antiviral activity against cucumber mosaic virus (CMV) isolated from cucumber and watermelon. Strophanthus speciosus and T. vulgare were also effective against potato virus $\mathrm{Y}$ (PVY) in tobacco and tomato plants, respectively $[143,145]$. Thuja orientalis extract was effective against eggplant blister mottled virus (EBMV) isolated from eggplant [146], fig leaf mottle-associated virus-1 (FLMaV-1) was identified in fig trees [147], and watermelon mosaic potyvirus (WMV) and zucchini yellow mosaic virus (ZYMV) were common to watermelon $[148,149]$. Prickly pear has also exhibited a notable antiviral activity against zucchini yellow mosaic virus (ZYMV) and squash mosaic virus (SqMV) isolated from zucchini (Cucurbita pepo L.) [142].

Different classes of phytochemicals have been implicated in the foregoing antiviral activities of plant extracts. These include alkaloids, coumarins, flavonoids, phenolics, and terpenoids amongst others. Alkaloids: 1-methoxycarbonyl$\beta$-carboline from methanolic extract of $P$. quassioides wood [136], drupacine and cephalotaxine from methanolic extract of C. sinensis leaves and branches [140], Opuntin B from aqueous extract of prickly pear cladode [142, 144]; flavonoids: Liquiritin from methanolic extract of G. glabra root [137, 150]; phenolics: gramniphenol C from a chromatographic fraction of A. graminifolia whole plant extract [138] and salicylic acid from aqueous extract of $S$. alba leaves and bark [48]; terpenoids: $1 \beta$-methoxydiversifolin-3-0-methyl ether and tagitinin $C$ isolated from methanol extract of $T$. diversifolia whole plant part [139], rhodoxanthin from ethanol extract of $T$. orientalis leaves and fruits [151, 152], spathodic acid-28-O- $\beta$-D-glucopyranoside and 5-methoxycoumarin-7-O- $\beta$-D-glycosidase (coumarin) from ethyl 
acetate extract of $A$. chinensis root bark [141]; and a variety of phytochemicals have been detected in methanol extract from T. vulgare flower [143] and ethanol extracts of S. speciosus leaves and fruits [145].

The use of microbes as effective producers of antiviral agents has also been exploited in the eradication of plant viruses. An example is the application of Bacillus amyloliquefaciens in the treatment of tobacco streak virus (TSV) in cotton plants [153] and broad bean wilt virus (BBWV), pepper mild mottle virus (PMMoV), and CMV in pepper [154]. Similarly, polysaccharides extract from Penicillium chrysogenum successfully inhibited the spread of TMV. In the same vein, secondary metabolites were isolated from Brucea javanica, namely brucein $\mathrm{B}$ and bruceantinol, had the highest inhibitory activity against pepper mottle virus (PepMoV) [155]; ningnanmycin, the first antiviral agent to be isolated from Strepcomces noursei var-xichangensisn, showed a notable activity against TMV [156]; an active constituent in Streptomyces hygroscopicus-cytosinpeptidemycin exhibited a potent antiviral activity against southern rice black-streaked dwarf virus (SRBSDV) and TMV [154, 157]. Figure 4 presents a summary of relevant virucidal molecules.

\section{Food Preservation: An Overview of Current Methods}

The need to maintain dietary value, composition, flavor, colour, $\mathrm{pH}$, and texture of a particular food product over long time is the reason behind food preservation [24, 158]. Spoilage in food is attributed to activities of microorganisms, which cause food degradation and oxidation, which leads to rancidity and browning of food. The ripening process which is caused by enzymes present after harvesting or slaughtering (in the case of animals) is the third cause of food spoilage. Several techniques have been employed in handling and conserving food to reduce wastage [24]. The different farm products such as meat, fish, fruits, vegetables, roots, and tubers are not preserved in the same way since they are of different composition. In food preservation, physical processes such as salting, drying, and boiling are employed, while chemical processes involve the use of different types of chemicals [158, 159]. Historically, approaches such as bagging, cooling, curing, drying, fermentation, heating, jelling, salting, and smoking were employed. However, in recent times, modern industrial techniques such as freezedrying, pasteurization, irradiation, vacuum packing, artificial food additive, and high-pressure food preservation are in vogue [24]. Generally, some microorganisms are harmful, while others are beneficial. The beneficial ones have been intentionally employed in the preservation of food products $[160,161]$. Drying and smoking involve the removal of water from the farm produce, thereby reducing the possibility of spoilage. Techniques such as sun drying, oven drying, roller drying, vacuum drying, spray drying, tunnel drying, and freeze-drying can be explored $[24,162]$. Irradiation combines sterilizing and drying of products such as fruits and vegetables to meet quarantine requirements for export. However, this process is not widely accepted by consumers due to uncertainties about health safety associated with the technology [24, 163, 164]. Majorly preservatives can be classified as antimicrobials or antioxidants preservatives. Antimicrobial preservatives inhibit the growth of spoilage organisms, which could be bacteria, fungi, or yeast. Examples include sodium benzoate, sodium nitrate, and potassium sorbate [165]. On the other hand, antioxidant preservatives hinder or slow down oxidation processes or inhibit factors that cause ripening/browning of farm produce after harvest. Examples include sodium succinate and ascorbic acid [19, 165].

3.1. Pitfalls of Current Methods in Food Preservation. The pitfalls observed in the current methods of preservation include a reduction in nutritional quality, unpleasant side effects, and diseases such as cancer in extreme cases. Prolonged drying/smoking and irradiation lead to loss of colour, flavor, aroma, texture, and vitamins $[24,163,166]$, while the use of sulfites in fruits have resulted in side effects such as headaches and allergies. Unexpected chemical interactions also occur between certain preservatives. For instance, sodium benzoate and ascorbic acid interact to produce carcinogens, thereby causing life-threatening diseases $[158,167,168]$. Similarly, nitrites and nitrate mostly which are used in meat product undergoes some reactions when consumed and turn into nitrous acid, which results in stomach cancer, brain tumors, and leukemia [169]. Studies on fermented and nonfermented soy foods revealed that the risk of gastric cancer development was associated with high consumption of fermented soy foods, while the high consumption rate of nonfermented soy foods reduced the risk of gastric cancer $[170,171]$. A summary of the negative effects of the current methods used in food preservation is shown in Table 3.

\subsection{Application of Natural Products in Food Preservation and} Their Advantages. The nature of food usually determines the kind of preservative to be employed [18]. Antioxidant preservatives are applied to oily food, while antimicrobial preservatives are applied to food containing an appreciable amount of water. However, both preservatives are required for food containing both oil and water, e.g., bread and sausages $[174,175]$. While antimicrobial agents inhibit the growth of microorganisms, and antioxidants hinder unwanted oxidation of oily content in food [18]. Examples of such natural antimicrobial preservatives are tea tree oil, turmeric oil, lemon balm extract, and neem oil, while ascorbic acid, tocopherols, and rosemary oil are popular examples of antioxidants preservatives [19, 20, 175].

3.2.1. Antimicrobial Preservatives. Several plant extracts have been investigated for their ability to serve as preservatives agents against foodborne pathogens. Recently, the antibacterial activity of pure compounds isolated from plant extracts has been reported. The potency of stigmasterol, an isolate of ethyl acetate fraction of Congea tomentosa stem against the growth of Aspergillus flavus, Aspergillus niger, Bacillus subtilis, Escherichia coli, 
<smiles>C=Cc1ncc(OC)c2c1[nH]c1c(OC)cccc12</smiles>

1-Methoxycarbonyl- $B$-carboline<smiles>O=C1CC(c2ccc(OC3O[C@H](CO)[C@@H](O)[C@H](O)[C@H]3O)cc2)Oc2cc(O)ccc21</smiles><smiles>COCC1OC(Oc2cc(OC)c3ccc(=O)oc3c2)C(O)C(O)C1OC</smiles>

5-Methoxy-coumarin-7-O-B-D-glycosidase<smiles></smiles>

Cephalotaxine<smiles>COc1ccc2c(c1)C=C[C@@H](c1ccc(O)c(C(=O)CCO)c1OC)O2</smiles>

Gramniphenol C<smiles>CO[C@H]1C[C@@]2(OC)O[C@@H]1[C@@](C)(C[C@@H](OC(=O)C(C)C)[C@H]1CC(=O)O[C@@H]1C=C(C)C)O2</smiles>

$1 B$-methoxydiversifolin-3-O-methyl ester

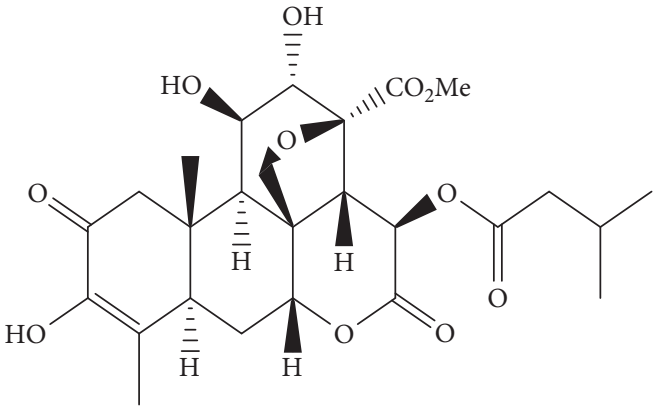

Brucein<smiles>O=C(O)c1ccccc1O</smiles>

Salicylic acid

FIgURE 4: Natural virucidal molecules.

TABLE 3: Pitfalls of the current methods in food preservation.

\begin{tabular}{|c|c|c|c|}
\hline Methods & Examples of food preserved & Disadvantages & References \\
\hline $\begin{array}{l}\text { Drying, smoking, freezing } \\
\text { irradiation, boiling }\end{array}$ & $\begin{array}{l}\text { Fish, tobacco leaves, and various } \\
\text { products }\end{array}$ & $\begin{array}{l}\text { After a long period time, the food starts losing its } \\
\text { colour, flavor, aroma, and vitamins }\end{array}$ & {$[24,162,163]$} \\
\hline Fermentation & Dairy products and wine & Increased risk of gastric cancer & {$[170,171]$} \\
\hline Salting & Meat and fish products & $\begin{array}{c}\text { When in excess, it causes high blood pressure and } \\
\text { kidney stone }\end{array}$ & {$[158,172]$} \\
\hline $\begin{array}{l}\text { Artificial food additives, e.g., } \\
\text { sodium bisulfite, }\end{array}$ & Fruits, vegetables & $\begin{array}{l}\text { They cause side reactions such as headaches and } \\
\text { allergies }\end{array}$ & {$[166]$} \\
\hline Sodium benzoate & $\begin{array}{c}\text { Carbonated drinks, fruit juice, and } \\
\text { pickles }\end{array}$ & Hyperactivity, leukemia, and other cancers & [158] \\
\hline Potassium sorbate & $\begin{array}{l}\text { Flavoured drinks, fine bakery } \\
\text { wares, bread, and rolls }\end{array}$ & Not yet established & [173] \\
\hline Nitrite or nitrate & Meat products & $\begin{array}{c}\text { Suspected to cause stomach cancer, brain tumors, } \\
\text { and leukemia }\end{array}$ & {$[169]$} \\
\hline
\end{tabular}

Penicillium digitatum, and Serratia liquefaciens, has been reported [176]. Similarly, dalpanitin and vicenin-3 isolated from ethyl acetate fraction of Derris scandens leaves effectively inhibited the growth of Staphylococcus aureus, Bacillus cereus, Pseudomonas aeruginosa, and E. coli [177]. 
Second, several extracts have been proven as potent against the activity of $S$. aureus isolates and their resistant strains (MRSA), P. aeruginosa, E. coli, Listeria monocytogenes, Salmonella typhimurium, Bacillus subtilis, Proteus mirabilis, Klebsiella sp, Salmonella typhi, Enterobacteriaceae, A. niger, A. flavus, Candida albicans, Penicillium notatum, and Rhizopus microspores. Examples of such botanical extracts include extracts from Cymbopogon citratus leaves [178], Garcinia brasiliensis leaves [179], Lepechinia meyenii leaves [180], cranberry pomace [181], Persea americana seeds [182], Siegesbeckia orientalis L. whole plant part [183], Chrysophyllum albidum seeds [184], Ferula caspica aerial parts [185], Azadirachta indica leaves [116, 186], red prickly pear fruit [187], and Citrus aurantium L. flower [188]. Also, essential oil from leaves, stem, fruit peels, cloves, flowers, rhizomes, and seeds of several plants such as Hymenaea cangaceira leaves [189], Vitex gardneriana leaves [190], Dalbergia pinnata stem [191], Citrus sp. fruit peels [192, 193], Allium sativum cloves, and Sesamum indicum L. seeds [194] showed antibacterial activities.

Although the active antimicrobial agents in these natural sources were not isolated before use, the activity of the extracts is a result of the inherent phytochemicals, which may be working together in synergy. The antimicrobial, antioxidant, and cytotoxic properties of the extracts have been attributed to phytochemicals such as citral, aspilactonol $\mathrm{B}$, and 8-methyl-6-prenylquercetin (found in C. citratus) [178], fukugetin and fukugiside (found in G. brasiliensis) [179], carnosic acid, carnosol, and rosmanol (found in $L$. meyenii) [180], and morin, myricetin, and rhamnetin (found in Cranberry) [181], while a wide range of phytochemicals such as alkaloids, cyanogenic glycosides, flavonoids, phenols, saponins, and tannins was found in P. Americana seed extract [182]. In the same vein, the ethyl acetate fraction of $S$. orientalis contained compounds such as $16 \beta, 17,18$-trihydroxy-ent-kauran-19-oic acid, 16 $\beta$-hydro-ent-kauran-17, 19-dioic acid, $16 \alpha, 17$-dihydroxy-ent-kauran-19-oic acid, and 17, 18-dihydroxy-ent-kauran-19-oic acid [183], germacrene $\mathrm{D}$, (E)-caryophyllene, $\alpha$-guaiene, and $\beta$-elemene (found in H. cangaceira) [189], caryophyllene oxide, 6,9guaiadiene, and cis-calamenene (found in V. gardneriana) [190], elemicin, methyl eugenol, and 4-allyl-2,6-dimethoxyphenol (found in D. pinnata) [191], and limonene (found in citrus oil) [192].

Some food products require preservatives because they are fragile and more susceptible to spoilage caused by microorganisms. Tomato fruit, an important example, was preserved using aqueous extracts of Moringa oleifera seed; the extract successfully inhibited three species of bacteria and five species of fungi [195]. Similarly, aqueous extracts from Carica papaya seed and Xylopia aethiopica pod elongated the shelf life of tomatoes and pepper [196]. Additionally, the ethanolic extract of Lippia citriodora leaves sufficiently prolonged the shelf life of strawberry fruit [197]. Studies by Choi et al. established the efficacy of aqueous extract from Camellia sinensis (L.) seed as a natural preservative in soy sauce and inhibited the growth of C. albicans and Zygosaccharomyces rouxii [198]. Another good example is rice puddings, a type of dairy product that was preserved using the methanolic extract of Citrus aurantium L. flower [188]. Fruit and vegetable smoothies are enriched with nutrients and vitamins but have a short life span. To prolong their shelf life, hydroethanolic extracts from Beta vulgaris L. (beet) leaves and stem, which also exerted inhibitory properties against the growth of Listeria innocua, Saccharomyces cerevisiae, and E. coli [199], were required.

The foregoing extracts exhibited both antimicrobial/ antioxidant properties due to the presence of certain alkaloids and carpaine in C. papaya [200]; eugenol, sarbiene, benzoic acid, and camphor in $X$. aethiopica [201]; assamsaponin A, assamsaponin B, and heasaponin E1 in C. sinensis [198]; quinic acid, linoleic acid methyl ester, and pentadecanoic acid in C. aurantium [188]; and vitexin-2-O-rhamnoside and vitexin-2-O-xyloside in B. vulgaris [199]. Also, salmon fish was preserved using aminoethyl-phloretin (AEP), a phloretin derivative from a flavonoid (phloretin) extracted from apples and 2-bromine ethylamine [202]. Furthermore, in a bit to establish the efficacy of the natural extracts as preservatives, Soumya et al., compared natural extracts from lemongrass (LG), clove, and cinnamon (CC) leaves with a synthetic antimicrobial preservative (calcium propionate). The synthetic and natural preservatives were incorporated in muffin batter and both LG and CC elongated the shelf life from 16 to 24 days [203]. Furthermore, Ribeiro et al. investigated the activity of Artemisia dracunculus (Tarragon) as a preservative for pizza dough. Antitumor and antimicrobial activities were observed in addition to the antioxidant activity of $A$. dracunculus extract. Hence, the use of $A$. dracunculus extract as a preservative is more beneficial than the use of ascorbic acid, since it would not require an additional (antimicrobial) preservative [204]. Hence, employing certain natural preservatives comes with additional benefits such as nutritional and medicinal fortification.

Apart from the use of plant extracts and phytochemicals, microbes have found increasing applications in the food industry. An active compound reuteri was isolated and purified from Lactobacillus reuteri, a probiotic microbe, and was used to inhibit the growth of food pathogens such as $L$. monocytogenes, Salmonella spp., and E. coli [205]. Also, a strain of Lactobacillus plantarum significantly inhibited the growth of food pathogens such as Aspergillus flavus, Aspergillus parasiticus, and Penicillium expansum in fresh cheese [206, 207]. Similarly, chitosan from Aspergillus brasiliensis was used in preserving and enhancing the quality of fish sausage, and it also has a complementary antimicrobial activity against yeast and molds, E. coli, Enterobacteriaceae, and S. aureus [208]. Furthermore, a strain of Enterococcus mundtii coupled with chitosan and sodium lactate remarkably inhibited the growth of Listeria innocua, Shewanella putrefaciens, and psychrophilic flora in fish [209]. Asides the use of plants, microbes have been employed as sources of preservative because they are easy to produce and generally nontoxic. The structures of these antimicrobial preservatives compounds are shown in Figure 5. 


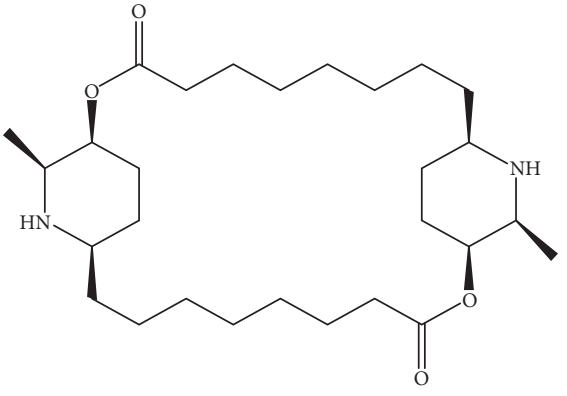

Carpaine<smiles>C=CCc1cc(OC)c(OC)c(OC)c1</smiles>

Elemicin

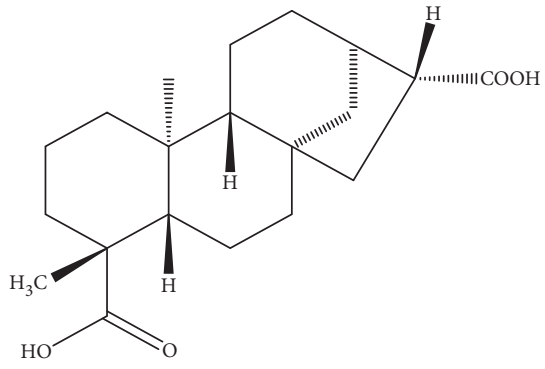

16B-hydro-ent-kauran-17, 19-dioic acid

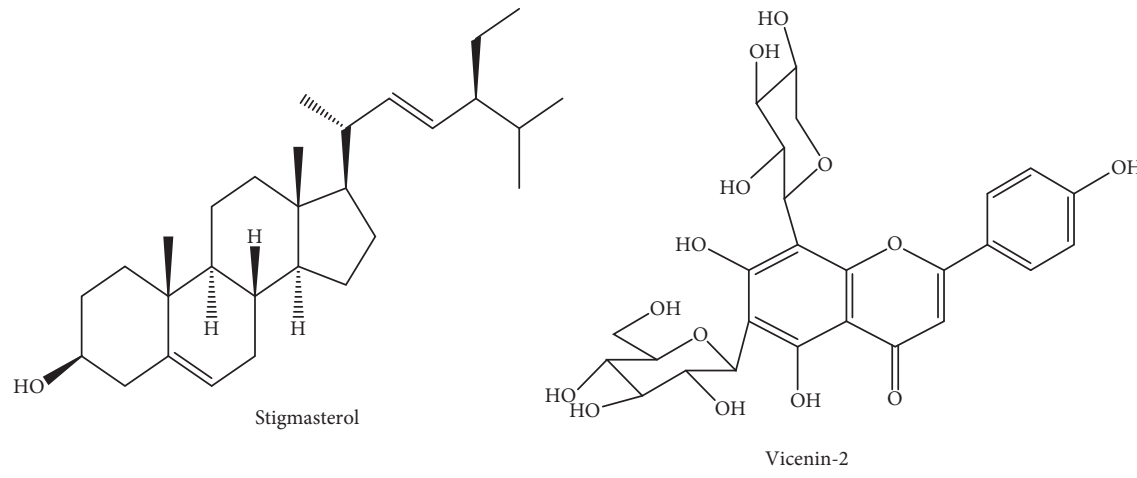<smiles>COc1cc(-c2coc3c(C(O)C(O)CO)c(O)cc(O)c3c2=O)ccc1O</smiles><smiles>CC(C)c1cc2c(c(O)c1O)[C@@]1(O)CCCC(C)(C)C1CC2</smiles>

Carnosic acid<smiles>O=C(O)[C@]1(O)C[C@@H](O)[C@H](O)[C@H](O)C1</smiles>

Quinic acid<smiles>CC(C)=CCCC(C)=CC=O</smiles>

Citral<smiles>C=CCc1ccc(O)c(OC)c1</smiles><smiles>O=C1c2c(O)cc(O)cc2O[C@H](c2c(O)cc(O)c3c(=O)cc(-c4ccc(O)c(O)c4)oc23)[C@H]1c1ccc(O)cc1</smiles>

Fukugetin

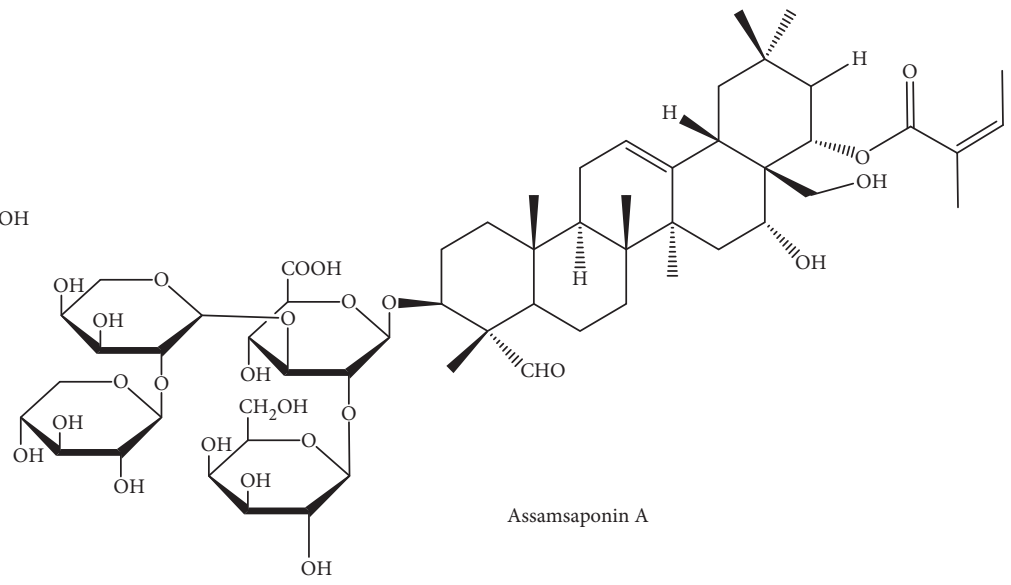

FIgURE 5: Natural antimicrobial-preservative molecules.

(1) Mechanism of Action. Studies have shown that different phytochemicals exhibit different biological activity based on substituent groups within their chemical structure. Generally, different ways through which antimicrobial agents exert their activity include inhibition of nucleic acid synthesis, inhibition of cytoplasmic membrane function, inhibition of energy metabolism, bacterial toxin production, and biofilm formation [210, 211].

Polyphenols make use of their hydroxyl group to attack the phospholipid bilayer of bacterial cell membranes, disrupting enzyme systems, which result in a limited supply of essential iron required for the growth of the microbes 
[212-214]. They also exert their activity via prooxidant damages to the cell membrane. For example, cinnamic acid ester and 3-p-trans-coumaroyl-2-hydroxyquinic acid (CHQA) disrupts the bacterial cytoplasmic membrane and interactions with membrane proteins and lipids. Also, CHQA inhibits DNA synthesis of the bacteria through the groove binding mode and reduces intracellular ATP [215-217]. Syringic acid, (+)-catechin, and vanillic acid function by inhibiting the formation of biofilm [218], while quercetin acts by inhibiting DNA gyrase. However, the presence of the hydroxyl group at C-5 in ring A, at C-4 in ring $\mathrm{B}$, and the methoxyl group at $\mathrm{C}-3$ and $\mathrm{C}-8$ in the $\mathrm{A}$ ring increases the inhibition [210].

Phytosterols such as stigmasterol have been known to mimic endogenous sterols based on their structural similarity. This gives them the ability to replace the hormone, thus disrupting the cell membrane. In the same vein, certain steroids suppress the ability of certain microbes to resist antibiotics by disrupting the multiple drug efflux pump proteins in multidrug-resistant microbes $[176,219]$. The presence of vinyl and peroxide moiety in steroids leads to an enhanced antibacterial activity $[176,220]$. A different mechanism of action has been observed for different types of alkaloids. An example is isoquinoline alkaloids, which act by inhibiting type I topoisomerases. Indolizidine and isoquinoline alkaloids exert their activity via the inhibition of nucleic acid synthesis, while polyamine alkaloids act by affecting the outer and cytoplasmic membranes [221]. Also, some evidence show that saponins owe their antimicrobial activity to the alteration of cell wall permeability [222, 223].

Furthermore, a variety of plant extracts have been found to successfully inhibit biofilm formation from various microbes mentioned earlier; such extracts which can be used as preventive coatings include $V$. gardneriana leaves [190], the aqueous extract of black grape residue [218], ethyl acetate fraction of Orostachys aponicas [224], methanol extract of Zingiber officinale, chloroform extract of Myristica fragrans [225], ethanol extract of Fraxinus angustifolia leaves and barks [226], and cardamom essential oil [227], while isolates such as (+)-nootkatone from the essential oil of grapefruit [228], and pulverulentone A from methylene chloridemethanol fraction (MME) of Callistemon citrinus leaves [229] can be used as a good alternative for preventing biofilm formation.

3.2.2. Antioxidants Preservatives. Natural extracts with antioxidant capacity have been employed in different food products ranging from meat, fruits, yogurt, and biscuits. Apart from microbial suppression/elimination, parameters that are used to assess the efficacy of preservatives include antioxidant capacity, external appearance, nutritional profile, $\mathrm{pH}$, and individual fatty acids. Various crude extracts have been applied to some of these examples. In meat preservation, extracts from C. citratus effectively increased the shelf life and improved the quality of chicken sausage [178], while ethanol extract from cranberry pomace and methanol extract from citrus coated on polyethylene terephthalate (PET) trays inhibited lipid oxidation in pork and cooked Turkey meat, respectively [181, 230]. Also, Tayengwa et al. incorporated extracts from grape pomace (GP) and citrus pulp (CP) into diets of steers, and results showed that diets with GP extract extended the shelf life of the beef after slaughtering compared to CP extracts [212]. Similarly, studies showed that extracts from Terminalia arjuna bark [231], red prickly pear fruit [187], and Cucumis melo L. seeds [232] were successfully employed to elongate the shelf life of beef. Phytochemicals such as alkaloids, coumarins, flavonoids, tannins, and terpenoids were identified in hydroalcoholic extracts of C. citratus leaves [178] and extracts from T. arjuna bark, fruits, stem, and leaves [233], while fifteen phenolic compounds including naringenin-7-Oglycoside, gallic acid, vanillic acid, and 4-hydroxybenzoic acid were identified in C. melo L. seeds [232]. These extracts contribute to nutritional, organoleptic, anticancer, anti-inflammatory, antimutagenic, antimicrobial, and antioxidant properties of foods to which they are applied [234-236]. In a related development, Aloe vera gel was utilized as a fruit coating in the preservation of C. papaya, raspberry, and Manilkara zapota L. fruit. A. vera gel reduced weight loss, suppressed fungal growth, maintained a high level of antioxidant capacity, and other parameters in the coated fruit during storage [237-239].

Similarly, a natural pigment found in tomatoes, "anthocyanin," whose production is usually enhanced by contaminations from pathogens and stress conditions were augmented in purple tomatoes to slow down ripening and vulnerability to Botrytis cinerea [240, 241]. Apart from this application, anthocyanin is a good antioxidant agent, which protects against chronic human disorders, cardiovascular diseases, and certain cancers $[242,243]$. Lemongrass can be applied either as an antioxidant or antimicrobial preservative agent. It was recently incorporated into herbal cookies to produce a variety that was not only nutritious but also possessed antioxidant, anticancer, anti-inflammation, and antidiabetic properties [21]. Also, Cucumis melo L. seeds powder was incorporated into bakery products to improve their functionality [232]. The chloroform and ethyl acetate extract of Ferula caspica aerial parts displayed a reasonable antimicrobial/antioxidant activity due to the presence of sesquiterpene derivatives, phenylpropanoid (laserine/2epilaserine), steroid, flavonoids, and a benzoic acid derivative [185]. Based on the fact that potato could recover from wounds by healing itself, its peel has proven to be a bioresource with great antioxidant [244]. The compounds which are produced when a potato is wounded include feruloyl quinic acid, ferulic acid, iso-feruloylputrescine, and coumaroylputrescine [245]. Decoctions from Matricaria recutita L. (chamomile) and Foeniculum vulgare Mill. (Fennel) leaves have been applied in the preservation of yogurt and biscuit. The chamomile decoction presented a higher antioxidant activity than potassium sorbate (E202) as shown by the observed parameters [246,247]. The structures of these antioxidant compounds are shown in Figure 6.

(1) Mechanism of Action. Antioxidants are known to reduce oxidative stress by providing the stability required in biologically generated free radicals. Different phytochemicals 
<smiles>O=C(/C=C/c1ccc(O)c(O)c1)O[C@@H]1C[C@@](O)(C(=O)O)C[C@H](O)[C@H]1O</smiles>

Feruloylquinic acid<smiles>COc1cc(C(=O)O)ccc1O</smiles>

Vanillic acid<smiles>[R12]Oc1c(-c2ccc(O)c([R12])c2)oc2cc(O)cc(O)c2c1=O</smiles>

Kaempferol-3-O-a-rhamnopyranoside<smiles>[R]c1cc([O-])c2cc([R])c([R])c([R])c2c1</smiles>

Anthocyanin<smiles>O=C(O[C@@H]1C[C@@](O)(C(=O)O)C[C@H](O)[C@H]1O)c1cc(O)c(O)c(O)c1</smiles><smiles>O=C(O)c1ccc(O)cc1</smiles>

4-hydroxybenzoic acid<smiles>O=c1cc(-c2ccc(O)cc2)oc2cc(OC3O[C@H](CO)[C@@H](O)[C@H](O)[C@H]3O)cc(O)c12</smiles>

Apigetrin (apigenin 7-glucoside)<smiles>O=C1C[C@@H](c2ccc(O)cc2)Oc2cc(O[C@@H]3O[C@H](CO)[C@@H](O)[C@H](O)[C@H]3O)cc(O)c21</smiles>

Naringenin-7-O-glycoside<smiles>NCCCCNC(=O)/C=C/c1ccc(O)cc1</smiles>

Coumaroylputrescine<smiles>O=C(/C=C/c1ccc(O)c(O)c1)O[C@H](C(=O)O)[C@@H](O)C(=O)O</smiles>

Caftaric acid<smiles>C/C=C(/C)C(=O)O[C@H](C)[C@H](OC(=O)/C(C)=C\C)c1cc(OC)c2c(c1)OCO2</smiles>

Laserine

Figure 6: Natural antioxidant-preservative molecules.

have been found to exert their antioxidant activity through pathways such as reactive species scavenging (free radicals, nonradicals, and transition metals), chelating effect, binding effect, and inhibition of lipoxygenase [248-250]. Typical examples are polyphenols such as flavonoid and phenolic compounds, which have a good antioxidant capacity and inhibit oxidative processes by either acting as a reactive species scavenger [183, 237, 251], lipoxygenase inhibitor $[212,231,252]$, or as reducing agents for metmyoglobin $[178,187]$. Salicylic acid acts by stimulating enzymes, such as superoxide dismutase, catalase, and peroxidase, while citric acid inhibits oxidative processes by binding to metals using its hydroxyl and carboxyl moiety [230]. Generally, alkaloids interact with reactive species by trapping them with hydroxyl groups in their structure, while their chelating effect on ferrous ions can be attributed to the presence of nitrogen moiety [253]. Particularly, indole, isoquinoline, isosteroid, and nicotine alkaloids act by scavenging free radicals and by reducing iron and molybdate [254-257]. Terpenoids reportedly exert their activity by inhibiting lipid oxidation and 
reducing oxidative stress [258]. Although not as much as other phytochemicals, saponins from different plant extracts have also been found to inhibit the formation of reactive oxygenated species [259-261].

\subsection{Challenges Associated with the Use of Natural Extracts in} Food Preservation. The benefits associated with the use of natural extract cannot be overestimated. However, some demerits are involved in the use of botanicals for food preservation.

3.3.1. Poor Thermal Stability. During extraction, the use of hot extraction techniques is expected to facilitate extracts production. However, this leads to thermal decomposition of vital phytochemicals responsible for the antimicrobial activity and antioxidant activity, thus rendering the extract impotent and forcing industrialists to source for sustainable alternatives [262-264]. These explain the fact that not all techniques are appropriate for the extraction of certain compounds. Studies have shown that thermo-labile components decompose or become unstable at high temperatures $[265,266]$. Flavanol and anthocyanins, for example, are affected by high temperatures [265]. Consequently, green techniques such as ultrasonic-assisted extraction, pressurized liquid extraction, natural deep eutectic solvent, and supercritical fluid extraction are suitable for extracting alkaloids, phenolic compounds, flavonoids, essential oils, terpenoids, saponins, and lipids in high yield [266-270]. Factors such as temperature, light, oxygen, and $\mathrm{pH}$, which affect the activity of various compounds, should be considered when choosing a particular technique for extraction.

\subsubsection{Toxicity Effect of Unrefined Crude Extracts. Most} crude extracts obtained from plants contain a mixture of compounds, which are used directly without any further purification. Thus, the active compounds are not separated from the inactive/toxic ones, which are responsible for crude extract toxicity [271, 272]. Hence, isolation of the active compounds which exert the antimicrobial/antioxidant activity helps to eradicate the toxic compounds, which are not needed in such therapeutic mixtures. Though the process of fractionating and isolating these bioactive compounds are often expensive, energy, and time consuming [273]; bioassay-guided fractionation of active compound is advised to reduce the complication that might arise $[176,177,198,213]$.

3.3.3. Low Yield of Pure Compounds. After extraction, quantification of the resulting natural product isolates usually reveals a low percentage yield. Hence, synthesizing these components becomes crucial. During synthesis, the stereochemistry of the compounds to be synthesized is very important because a wrong configuration can give rise to unsolicited outcomes. Apart from synthesizing natural products, there are various avenues via which the yield of natural products can be enhanced. Chromatographic methods such as countercurrent chromatography can give a reasonable amount of bioactive compounds [274].
Furthermore, via gene expression, the percentage presence of certain phytochemicals could be boosted to afford an increase in the percentage yield of the compound of our interest. Overexpressing certain genes in plants such as $\alpha$-amyrin synthase in Ipomoea batatas Lam can give rise to increased yield of urs-13(18)-ene- $3 \beta$-yl acetate [98], just as glucosyltransferases, which can stimulate the production of anthocyanin diglucoside in Solanum tuberosum [240]. Squalene synthase in Panax ginseng increased the yield of triterpene saponins and phytosterols [275], while endoprotease enhanced the production of isoflavone and peptides in soy pulp by-product [276].

3.3.4. Unpleasant Effects on Sensory Properties. In addition to the foregoing, some crude extracts may sometimes have a particular odor, taste, colour, flavor, which affect the sensory properties of food even at low concentrations [203]. Many extracts have been found to rather enhance the sensory properties of the food product [187, 199, 246, 277]. However, there are a few expectations. Studies showed that extracts from goji berry by-product were used as substitutes for flour in baking cookies and muffin to different extents $(0,10,20$, 30 , and $40 \mathrm{~g} / 100 \mathrm{~g}$ ). It was observed that at a substitution extent of $40 \mathrm{~g} / 100 \mathrm{~g}$, the pastries had a bitter aftertaste and a displeasing texture, while at lower substitution rate, it gave appreciable results [278]. Similarly, the use of O. ficus-indica mucilage in bread production increased the antioxidant capacity of the bread. However, higher crust colour and more intense odor also accompanied the new products [279]. The chemical composition of the various extracts should be taken into consideration as different phytochemicals react differently with several food components. A proper analysis should always precede natural product applications in food preservation to avoid undesired chemical interactions' unpleasant results.

\section{Plant Extracts as Feed for Silver Nanoparticle Production}

Apart from the direct application of plant extracts in crop protection and food preservatives, several plant extracts, fractions, and isolates have served as reducing agents and stabilizers in the preparation of nanoparticles [280-282]. Since the advent of nanoparticles, different kinds of materials have been employed in their synthesis. Nanoparticles could be carbon-based, metal-based, lipid-based, ceramic, semiconductors, or polymeric nanoparticles [283]. Among the numerous examples of metal-based nanoparticles, silver nanoparticles (AgNPs) have received a lot of attention because of the simplicity of its synthesis and its notable antimicrobial activity $[167,284,285]$. There are two main approaches to the synthesis of nanoparticles: top-down and bottom-up. In the top-down approach, nanoparticles are synthesized from macroscopic materials. This approach is expensive, slow, and not suitable for large scale production when compared to the bottom-up approach. The top-down approach involves processes such as evaporation/condensation, laser pyrolysis, and ionic/electronic irradiation. 
TABLE 4: Green synthesized silver nanoparticles from plant and their applications in crop protection and food preservation.

\begin{tabular}{|c|c|c|c|}
\hline Plants material & Extracts & Possible applications & References \\
\hline Tithonia diversifolia leaf & Aqueous & As an antimicrobial agent in the pharmaceutical and food industries & [293] \\
\hline Musa paradisiaca midrib & " & Nano-ice for the preservation of fish and other food products & [297] \\
\hline Oolong tea & ” & $\begin{array}{l}\text { As a fruit coating to preserve postharvest qualities of fruits, e.g., cherry } \\
\text { tomatoes }\end{array}$ & {$[280]$} \\
\hline Melia azedarach leaf & $"$ & $\begin{array}{c}\text { As an antifungal agent against Verticillium dahliae in eggplants and } \\
\text { edible fruit coating to preserve }\end{array}$ & {$[298,299]$} \\
\hline Zea mays L. corn flour & ” & For cancer treatment and radical scavenging agent & [300] \\
\hline Sesame cake oil & ” & As an antibacterial and antitumor agent & [301] \\
\hline Belladonna mother tincture & ” & Antimicrobial agent and anti-inflammatory agent & {$[302]$} \\
\hline Acalypha indica leaf & ” & As a fruit coating, antioxidant, and good antifungal agent. & [303] \\
\hline Phyllanthus emblica fruit & ” & As an antimicrobial agent against Acidovorax oryzae strain & [281] \\
\hline Annona reticulate leaf & $"$ & $\begin{array}{c}\text { As larvicidal agent against dengue vector (Aedes aegypti) and } \\
\text { antimicrobial activity }\end{array}$ & {$[304]$} \\
\hline $\begin{array}{l}\text { Camellia sinensis } \\
\text { leaf + polyethylene glycol (PEG) }\end{array}$ & ” & As an antimicrobial agent against food pathogens & {$[305]$} \\
\hline Grape pomace and orange peels & ” & ” & [306] \\
\hline Persea americana seeds & ” & $"$ & [307] \\
\hline Cocoa pod & ” & $\begin{array}{c}\text { Growth enhancer for root and shoot elongation for more nutrient } \\
\text { absorption, a good antioxidant, prolongs shelf life, high tolerance level } \\
\text { against fungi, and nematodes }\end{array}$ & [308] \\
\hline Euphorbia tirucalli latex & ” & As nematicides against Meloidogyne incognita in tomatoes & [309] \\
\hline Suaeda maritima & Ethanol & As biopesticides to fight against Aedes aegypti and spodoptera litura & {$[310]$} \\
\hline Lindera strychnifolia roots & $\begin{array}{c}\text { Aqueous and } \\
\text { ethanol }\end{array}$ & Antioxidants wound healing and anticancer agents & [311] \\
\hline
\end{tabular}

Currently, the most utilized top-down approach is the photolithography, which finds application in the manufacture of computer chip-sand. However, in the "bottom-up approach," the applied principle is different, and the nanoparticle synthesis is less expensive [286, 287]. Physical, chemical, and biological methods are utilized in the bottomup approach. The build-up of nanostructure molecules in the physical method includes several techniques amongst which chemical vapor deposition is most popular [288, 289]. The techniques in the chemical method could be classified under the following categories: colloidal, sol-gel processing, microemulsion of oil-water, hydrothermal synthesis, polyol, sonochemical synthesis, and electrodeposition [290]. The chemical method is carried out using wet chemistry, ion implantation, and product functionalization routes. Wet chemistry routes remain the most widely explored among the chemical reduction methods used in the synthesis of silver nanoparticles, which involves the use of sodium borohydride, reducing sugars, citrate as reducing agents, silver mirror reaction, $\mathrm{N}, \mathrm{N}$-dimethylformamide (DMF), and polyol process seed-mediated growth [291-293]. Researchers, in the search of the improved method, have identified biological methods as economically friendly and environmentally benign without any reported known toxicity. The biological route mainly involves the use of microorganisms and plant extracts [294, 295]. Green synthesis of silver nanoparticles has been widely employed because it is cheaper, safer, and ecofriendly [284, 296]. Interestingly, nanoparticles usually display a higher antimicrobial activity when compared with the plant extracts, which executes the reduction of the metallic ions and serves as the capping agents. Recent and notable examples of such green synthesis and their application are captured in Table 4.
As nanoparticles application continues to expand, concerns have begun to emerge about the possible toxicity of the materials [283]. However, these nanoparticles do not pose serious threats as seen in other methods [312].

\section{Conclusion}

The foregoing review shows that natural product has gained reasonable ground in crop protection and food preservation. Various extracts from different plant sources execute protective and preventive properties via known classes of secondary metabolites that they contain. Several studies directly employed crude extracts, while some studies fractionated the extract into less complex forms before application. A few indepth studies, however, isolated the active constituents, which were responsible for the activities under review. Although the active natural molecules are usually present in little quantities, they have proven to be better alternatives compared to their synthetic counterparts, which have been hitherto employed. There is a widely spread notion that natural remedies are safer than synthetic chemicals. Hence, the growing interest of scientists in authenticating the efficiency of natural products in crop protection, food preservation, and other medicinal applications. Although various crude extract have given impressive results in this direction, isolating the phytochemicals such as flavonoids, alkaloids, tannins, and saponins could provide better solutions to various agro-related challenges. This approach deserves more scientific attention in the future. An interesting development is the application of plant extract for the green synthesis of nanoparticles, which tend to proffer impressive results. Particularly, silver nanoparticles (AgNPs) have been applied in crop protection and food preservation. 
However, the rising toxicity and environmental concerns about AgNPs are also worthy of further research [312]. Government policies should be put in place to encourage the commercialization of natural-based agrochemicals, and farmers should be enlightened about the benefits of these health and environment-friendly products.

\section{Abbreviations}

AHAS: Acetohydroxyacid synthase

AR: Alkylresorcinols

CC: $\quad$ Clove and cinnamon

CMV: Cucumber mosaic virus

EPA: Environmental Protection Agency

FAW: Fall armyworm

FAO: Food and Agriculture Organization

GM: $\quad$ Genetically modified

HPLC: High-performance liquid chromatography

LG: $\quad$ Lemon grass

AgNPs: Silver nanoparticles

TMV: Tobacco mosaic virus

WHO: World Health Organization.

\section{Data Availability}

The data used to support this review article are available in major scientific databases such as Scopus, Google scholar, PubMed, Science Direct, and other relevant sources. Keywords such as crop protection, food protection, natural products, pesticides, insecticides, herbicides, and natural food preservative will assist in obtaining these articles.

\section{Conflicts of Interest}

The authors declare that they have no conflicts of interest.

\section{References}

[1] F. E. Dayan, C. L. Cantrell, and S. O. Duke, "Natural products in crop protection," Bioorganic \& Medicinal Chemistry, vol. 17, no. 12, pp. 4022-4034, 2009.

[2] US EPA, 1996 Food Quality Protection Act: Draft Implementation Plan, US EPA, Washington, DC, USA, 1997.

[3] K. L. Njoku, C. V. Ezeh, F. O. Obidi, and M. O. Akinola, "Assessment of pesticide residue levels in vegetables sold in some markets in Lagos state, Nigeria," Nigerian Journal of Biotechnology, vol. 32, no. 1, p. 53, 2017.

[4] J. E. Casida, "Pest toxicology: the primary mechanisms of pesticide action," in Hayes' Handbook of Pesticide Toxicology, pp. 103-117, Elsevier B.V., Amsterdam, Netherlands, 2010.

[5] B. M. Keikotlhaile and P. Spanoghe, "Pesticide residues in fruits and vegetables from Croatian market," Acta Aliment, vol. 33, no. 3, pp. 275-284, 2004.

[6] S. Sitaramaraju, N. V. V. S. D. Prasad, V. R. Chenga, and E. Narayana, "Impact of pesticides used for crop production on the environment," Journal of Chemical and Pharmaceutical Sciences, vol. 3, pp. 75-79, 2014.

[7] R. Dasika, S. Tangirala, and P. Naishadham, "Pesticide residue analysis of fruits and vegetables," Journal of Environmental Chemistry and Ecotoxicology, vol. 4, no. 2, pp. 19-28, 2012.
[8] Y. H. Chiu, M. C. Afeiche, A. J. Gaskins et al., "Fruit and vegetable intake and their pesticide residues in relation to semen quality among men from a fertility clinic," Human Reproduction, vol. 30, no. 6, pp. 1342-1351, 2015.

[9] FAO \& WHO, Pesticide Residues in Food 2013, WHO, Geneva, Switzerland, 2013.

[10] FAO \& WHO, Joint FAO/WHO Food Standards Programme Codex Alimentarius Commission, WHO, Geneva, Switzerland, 2005.

[11] M. J. Perry, "Effects of environmental and occupational pesticide exposure on human sperm: a systematic review," Human Reproduction Update, vol. 14, no. 3, pp. 233-242, 2008.

[12] M. J. Perry, S. A. Venners, X. Chen et al., "Organophosphorous pesticide exposures and sperm quality," Reproductive Toxicology, vol. 31, no. 1, pp. 75-79, 2011.

[13] S. E. Martenies and M. J. Perry, "Environmental and occupational pesticide exposure and human sperm parameters: a systematic review," Toxicology, vol. 307, pp. 66-73, 2013.

[14] R. Recio-vega, G. Ocampo-gómez, V. H. Borja-aburto, J. Moran-martínez, and M. E. Cebrian-garcia, "Organophosphorus pesticide exposure decreases sperm quality: association between sperm parameters and urinary pesticide levels," Journal of Applied Toxicology, vol. 28, pp. 674-680, 2008.

[15] C. Fortes, S. Mastroeni, M. A. Pilla, G. Antonelli, L. Lunghini, and C. Aprea, "The relation between dietary habits and urinary levels of 3-phenoxybenzoic acid, a pyrethroid metabolite," Food and Chemical Toxicology, vol. 52, pp. 91-96, 2013.

[16] WHO and FAO, Pesticide Residues in Food 2016 Special Session of the Joint FAO/WHO Meeting on Pesticide Residues Report 2016, WHO, Geneva, Switzerland, 2016.

[17] D. Pimentel, "Pesticides and pest control," Integrated Pest Management: Innovation-Development Process, vol. 1, pp. 83-87, 2009.

[18] Z. Sharif, F. Mustapha, J. Jai, N. Mohd Yusof, and N. Zaki, "Review on methods for preservation and natural preservatives for extending the food longevity," Chemical Engineering Research Bulletin, vol. 19, p. 145, 2017.

[19] G. D. Mogoşanu, A. M. Grumezescu, C. Bejenaru, and L. E. Bejenaru, "Natural Products Used for Food Preservation," Food Preservation, pp. 365-411, 2017.

[20] N. F. Santos-Sánchez, R. Salas-Coronado, R. Salas-Coronado, R. Valadez-Blanco, B. Hernández-Carlos, and P. C. Guadarrama-Mendoza, "Natural antioxidant extracts as food preservatives," Acta Scientiarum Polonorum Technologia Alimentaria, vol. 16, no. 4, pp. 361-370, 2017.

[21] P. Thorat, R. Kshirsagar, A. Sawate, and B. Patil, "Effect of lemongrass powder on proximate and phytochemical content of herbal cookies," Journal of Pharmacognosy and Phytochemistry, vol. 155, no. 66, pp. 155-159, 2017, http:// www.phytojournal.com/archives/2017/vol6issue6/PartC/65-463-240.pdf.

[22] J. Vora, A. Srivastava, and H. Modi, “Antibacterial and antioxidant strategies for acne treatment through plant extracts," Informatics in Medicine Unlocked, vol. 13, pp. 128-132, 2018.

[23] Y. Yan, Q. Liu, S. E. Jacobsen, and Y. Tang, "The impact and prospect of natural product discovery in agriculture," EMBO Reports, vol. 19, no. 11, pp. 1-6, 2018.

[24] A. A. Olunike, "Storage, preservation, and processing of farm produce," Food Science and Quality Management, vol. 27, 
pp. 28-33, 2014, http://www.iiste.org/Journals/index.php/ FSQM/article/viewFile/12881/13224.

[25] A. A. Alex, N. K. Longinus, A. M. Olatunde, and N. V. Chinedu, "Pesticides-related knowledge, attitude, and safety practices among small-scale vegetable farmers in lagoon wetlands, Lagos, Nigeria," J. Agric. Environ. Int. Dev, vol. 112, no. 1, pp. 81-99, 2018.

[26] US EPA, Types of Pesticide Ingredients, US EPA, Washington, DC, USA.

[27] F. S. Sabra and E. E. Mehana, "Pesticides toxicity in fish with particular reference to insecticides," Asian Journal of Agricultural and Food Sciences, vol. 3, no. 1, pp. 40-60, 2015.

[28] P. Koli, N. R. Bhardwaj, and S. K. Mahawer, "Agrochemicals: harmful and beneficial effects of climate changing scenarios," in Climate Change and Agricultural Ecosystems, pp. 65-94, Elsevier Inc., Amsterdam, Netherlands, 2019.

[29] C. Yang, C. Hamel, V. Vujanovic, and Y. Gan, "Fungicide: modes of action and possible impact on nontarget microorganisms," ISRN Ecology, vol. 2011, pp. 1-8, 2011.

[30] A. Wssa et al., "Common and chemical names of herbicides approved by the Weed Science Society of America," Weed Sci, vol. 62, no. 4, pp. 679-687, 2014.

[31] S. I. Sherwani, I. A. Arif, and H. A. Khan, "Modes of action of different classes of herbicides," in Herbicides, Physiology of Action, and Safety, pp. 165-186, IntechOpen, London, UK, 2015.

[32] G. Al-Samarai, W. Mahdi, and B. Al-Hilali, "Reducing environmental pollution by chemical herbicides using natural plant derivatives: allelopathy effect," Annals of Agricultural and Environmental Medicine, vol. 25, no. 3, pp. 449-452, 2018.

[33] EPA, Appendix G: Herbicides, Trade Names, and Target Species, vol. 1, EPA, Washington, DC, USA, 2002.

[34] J. W. Pscheidt, Fungicide Theory of Use and Mode of Action, Oregon State University, Corvallis, OR, USA, 2002.

[35] H. Mohamed and H. El-beltagi, "The role of systemic and nonsystemic fungicides on the physiological and biochemical parameters in Gossypium hirsutum plant, implications for defense responses," Fresenius Environmental Bulletin, vol. 27 , no. 12, pp. 8585-8593, 2018.

[36] C. J. R. Klittich and S. L. Ray, "Effects of physical properties on the translaminar activity of fungicides," Pesticide Biochemistry and Physiology, vol. 107, no. 3, pp. 351-359, 2013.

[37] H. Masih, J. K. Peter, and P. Tripathi, "A comparative evaluation of the antifungal activity of medicinal plant extracts and chemical fungicides against four plant pathogens," International Journal of Current Microbiology and Applied Sciences, vol. 3, no. 5, pp. 97-109, 2014.

[38] M. Camara, E. Faye, S. Modou Sarr, E. Victor Coly, and M. Gueye, "Comparative effects of natural and synthetic fungicides on the pink root disease of onion (Allium cepa L.) in nursery," Agricultural Sciences, vol. 8, no. 8, pp. 743-750, 2017.

[39] P. Rajbongshi and D. Yumnam, "A study on the effect of some fungicides on the population of soil mycoflora," Journal Of International Academic Research For Multidisciplinary, vol. 1, no. 12, pp. 99-106, 2014.

[40] BASF, Insecticide Mode of Action, BASF Corporation, Ludwigshafen, Germany, 2013.

[41] A. Ghosal, "Mode of action of insecticides," Applied Entomology and Zoology, vol. 1, pp. 1-17, 2018.

[42] R. C. Torres, A. G. Garbo, and R. Z. M. L. Walde, "Larvicidal activity of Persea americana Mill. against Aedes aegypti,"
Asian Pacific Journal of Tropical Medicine, vol. 7, no. S1, pp. S167-S170, 2014.

[43] B. Sisay, T. Tefera, M. Wakgari, G. Ayalew, and E. Mendesil, "The efficacy of selected synthetic insecticides and botanicals against fall armyworm, Spodoptera frugiperda, in maize," Insects, vol. 10, no. 2, pp. 45-2, 2019.

[44] F. Sánchez-bayo and H. A. Tennekes, "Impact of systemic insecticides on organisms and ecosystems," in Insecticides Development of Safer and More Effective Technologies, pp. 387-416, IntechOpen Limited, London, UK, 2013.

[45] Y. Rajashekar and T. Shivanandappa, "Mode of action of the natural insecticide, decaleside, involves sodium pump inhibition," PLoS One, vol. 12, no. 1, pp. e0170836-15, 2017.

[46] D. Dey, "Impact of indiscriminate use of insecticide on environmental pollution," International Journal of Plant Protection, vol. 9, no. 1, pp. 264-267, 2016.

[47] H. M. Waziri, "Plants as antiviral agents," Journal of Plant Pathology \& Microbiology, vol. 6, no. 2, pp. 1-5, 2015.

[48] M. Sofy, M. Elnosary, and A. R. Sofy, "Salix alba extract induces systemic resistance in Cucumis sativus infected by cucumber mosaic virus," Natural Science, vol. 16, no. 2, pp. 107-113, 2018.

[49] S. K. Saxena, S. Saxena, R. Saxena, M. Arvinda Swamy, A. Gupta, and M. P. Nair, "Emerging trends, challenges and prospects in antiviral therapeutics and drug development for infectious diseases," Electronic Journal of Biology, vol. 6, no. 2, pp. 26-31, 2010, http://ejbio.imedpub.com/emergingtrends-challenges-and-prospects-in-antiviraltherapeuticsand-drug-development-for-infectious-diseases.pdf.

[50] X.-y. Li and B.-a. Song, "Progress in the development and application of plant-based antiviral agents," Journal of Integrative Agriculture, vol. 16, no. 12, pp. 2772-2783, 2017.

[51] W. Islam, M. Qasim, A. Noman, M. Tayyab, S. Chen, and L. Wang, "Management of tobacco mosaic virus through natural metabolites," Records of Natural Products, vol. 12, no. 5, pp. 403-415, 2018.

[52] C. R. Ballal and A. Verghese, "New horizons in insect science: towards sustainable pest management," New Horizons in Insect Science: Towards Sustainable Pest, Springer Nature, Cham, Switzerland, 2015.

[53] M. Lorito and S. L. Woo, "Trichoderma: a multipurpose tool for integrated pest management," in Principles of PlantMicrobe Interactions, B. Lugtenberg, Ed., pp. 345-353, Springer International Publishing, Cham, Switzerland, 2015.

[54] K. Król, R. Kao, and J. Hernik, "The scarecrow as an indicator of changes in the cultural heritage of rural Poland," Sustainability, vol. 11, no. 23, pp. 6857-6923, 2019.

[55] J. P. Mitchell, A. Shrestha, and S. Irmak, "Trade-offs between winter cover crop production and soil water depletion in the San Joaquin Valley, California," Journal of Soil and Water Conservation, vol. 70, no. 6, pp. 430-440, 2015.

[56] E. E. Jorgensen, T. J. Canfield, and P. M. Mayer, "Crop protection contributions toward agricultural productivity," CAST, vol. 58, pp. 1-20, 2017.

[57] K. Datta, N. Baisakh, K. Maung Thet, J. Tu, and S. Datta, "Pyramiding transgenes for multiple resistance in rice against bacterial blight, yellow stem borer, and sheath blight," Theoretical and Applied Genetics, vol. 106, no. 1, pp. 1-8, 2002.

[58] R. Bock, "Plastid biotechnology: prospects for herbicide and insect resistance, metabolic engineering, and molecular farming," Current Opinion in Biotechnology, vol. 18, no. 2, pp. 100-106, 2007. 
[59] K. A. Lutz, J. E. Knapp, and P. Maliga, "Expression of bar in the plastid genome confers herbicide resistance," Plant Physiology, vol. 125, no. 4, pp. 1585-1590, 2001.

[60] A. Hameed et al., "Biosafety assessment of locally developed transgenic sugarcane," Journal of Animal and Plant Sciences, vol. 26, no. 4, pp. 1124-1132, 2016.

[61] R. W. Bretveld, C. M. Thomas, P. T. Scheepers, G. A. Zielhuis, and N. Roeleveld, "Pesticide exposure: the hormonal function of the female reproductive system disrupted?" Reproductive Biology and Endocrinology, vol. 4, no. 1, p. 30, 2006.

[62] V. Bencko and F. Yan Li Foong, "The history of arsenical pesticides and health risks related to the use of Agent Blue," Annals of Agricultural and Environmental Medicine, vol. 24, no. 2, pp. 312-316, 2017.

[63] R. Spiewak, "Pesticides as a cause of occupational skin diseases in farmers," Annals of Agricultural and Environmental Medicine, vol. 8, pp. 1-5, 2001.

[64] K. T. Jørgensen, M. S. Jensen, G. V. Toft, A. D. Larsen, J. P. Bonde, and K. S. Hougaard, "Risk of cryptorchidism among sons of horticultural workers and farmers in Denmark," Scandinavian Journal of Work, Environment \& Health, vol. 40, no. 3, pp. 323-330, 2014.

[65] S. L. Farr, G. S. Cooper, J. Cai, D. A. Savitz, and D. P. Sandler, "Pesticide use and menstrual cycle characteristics among premenopausal women in the agricultural health study," American Journal of Epidemiology, vol. 160, no. 12, pp. 1194-1204, 2004.

[66] R. Harari, J. Julvez, K. Murata et al., "Neurobehavioral deficits and increased blood pressure in school-age children prenatally exposed to pesticides," Environmental Health Perspectives, vol. 118, no. 6, pp. 890-896, 2010.

[67] D. W. Cole, R. Cole, S. J. Gaydos et al., "Aquaculture: environmental, toxicological, and health issues," International Journal of Hygiene and Environmental Health, vol. 212, no. 4, pp. 369-377, 2009.

[68] S. Satyanarayan, J. P. K. A. Satyanarayan, and S. Verma, "Histopathological changes due to some chlorinated hydrocarbon pesticides in the tissues to Cyprinus carpio," IOSR Journal of Pharmacy (IOSRPHR), vol. 2, no. 6, pp. 60-66, 2012.

[69] K. Satyavardhan, "A comparative toxicity evaluation and behavioral observations of fresh water fishes to fenvalerate," Middle-East Journal of Scientific Research, vol. 13, no. 2, pp. 133-136, 2013.

[70] S. R. Marigoudar, R. N. Ahmed, and M. David, "Cypermethrin induced respiratory and behavioural responses of the freshwater teleost, Labeo rohita (Hamilton)," Veterinarski Arhiv, vol. 79, no. 6, pp. 583-590, 2009.

[71] H. M. Dutta and H. J. M. Meijer, "Sublethal effects of diazinon on the structure of the testis of bluegill, Lepomis macrochirus: a microscopic analysis," Environmental Pollution, vol. 125, no. 3, pp. 355-360, 2003.

[72] M. Banaee, "Physiological dysfunction in fish after insecticides exposure," in Insecticides-Development of Safer and More Effective Technologies, pp. 103-143, IntechOpen Limited, London, UK, 2013.

[73] L. A. Helfrich, D. L. Weigmann, and E. R. Stinson, Pesticides and Aquatic Animals: A Guide to Reducing Impacts on Aquatic Systems Acknowledgments, VCE Publications, Petersburg, VA, USA, 2009.

[74] R. Ewing, "Diminishing returns: salmon decline and pesticides," Oregon Pesticide Education Network, 1999.
[75] M. Eslamiamirabadi, J. D. Burton, F. L. de los Reyes, and J. J. Ducoste, "Assessment of alternative herbicides for residential sewer root treatment and their effects on downstream treatment plant nitrification," Journal of Environmental Management, vol. 258, Article ID 110058, 2020.

[76] D. Pimentel, "Environmental and economic costs of the application of pesticides primarily in the United States," Environment, Development and Sustainability, vol. 7, no. 2, pp. 229-252, 2005.

[77] D. Babendreier, "23 pros and cons of biological control," in Ecologicial studies (Analysis and Synthesis), W. Nentwig, Ed., vol. 193, pp. 403-418, Springer-Verlag, Berlin, Germany, 2008.

[78] M. D. Owen and I. A. Zelaya, "Herbicide-resistant crops and weed resistance to herbicides," Pest Management Science, vol. 61, no. 3, pp. 301-311, 2005.

[79] C. J. de Vos and M. Swanenburg, "Health effects of feeding genetically modified (GM) crops to livestock animals: a review," Food and Chemical Toxicology, vol. 117, pp. 3-12, 2018.

[80] T. Morikawa, H. Wanibuchi, K. Morimura, M. Ogawa, and S. Fukushima, "Promotion of skin carcinogenesis by dimethylarsinic acid in keratin (K6)/ODC transgenic mice," Japanese Journal of Cancer Research, vol. 91, no. 6, pp. 579-581, 2000.

[81] P. N. Baligar and B. B. Kaliwal, "Induction of gonadal toxicity to female rats after chronic exposure to mancozeb," Industrial Health, vol. 39, no. 3, pp. 235-243, 2001.

[82] B. B. Bindali and B. B. Kaliwal, "Anti-implantation effect of a carbamate fungicide mancozeb in Albino mice," Industrial Health, vol. 40, no. 2, pp. 191-197, 2002.

[83] Y. Shimokawatoko, T. Yamaguchi, N. Sato, and H. Tanaka, "Development of the novel insecticide spinetoram (DIANA $\left.{ }^{\circledR}\right)$," Simitomo Kagaku, pp. 1-14, 2012.

[84] D. Bednarek, K. Dudek, K. Kwiatek, M. Świątkiewicz, S. Świątkiewicz, and J. Strzetelski, "Effect of a diet composed of genetically modified feed components on the selected immune parameters in pigs, cattle, and poultry," Bulletin of the Veterinary Institute in Pulawy, vol. 57, no. 2, pp. 209-217, 2013.

[85] K. Jabran, G. Mahajan, V. Sardana, and B. S. Chauhan, "Allelopathy for weed control in agricultural systems," Crop Protection, vol. 72, pp. 57-65, 2015.

[86] R. A. El-Mergawi and A. I. Al-Humaid, "Searching for natural herbicides in methanol extracts of eight plant species," Bulletin of the National Research Centre, vol. 43, no. 1, 2019.

[87] B. W. B. Kueh, S. Yusup, N. Osman, and N. H. Ramli, "Analysis of Melaleuca cajuputi extract as the potential herbicides for paddy weeds," Sustainable Chemistry and Pharmacy, vol. 11, pp. 36-40, 2019.

[88] Q. Xu, H. Xie, H. Xiao, and X. Wei, "Phenolic constituents from the roots of Mikania micrantha and their allelopathic effects," Journal of Agricultural and Food Chemistry, vol. 61, no. 30, pp. 7309-7314, 2013.

[89] M. S. S. Carvalho, L. F. Andrade-Vieira, F. E. d. Santos, F. F. Correa, M. das Graças Cardoso, and L. R. Vilela, "Allelopathic potential and phytochemical screening of ethanolic extracts from five species of Amaranthus spp. in the plant model Lactuca sativa," Scientia Horticulturae, vol. 245, pp. 90-98, 2019.

[90] M. T. I. Shajib, H. A. Pedersen, A. G. Mortensen, P. Kudsk, and I. S. Fomsgaard, "Phytotoxic effect, uptake, and transformation of biochanin A in selected weed species," Journal 
of Agricultural and Food Chemistry, vol. 60, no. 43, pp. 10715-10722, 2012.

[91] L. Nebo, R. M. Varela, J. M. G. Molinillo et al., "Phytotoxicity of alkaloids, coumarins, and flavonoids isolated from 11 species belonging to the Rutaceae and Meliaceae families," Phytochemistry Letters, vol. 8, no. 1, pp. 226-232, 2014.

[92] C. O. Adetunji, J. K. Oloke, M. Pradeep, A. P. Oluyori, R. S. Jolly, and O. M. Bello, "Mellein, a dihydroisocoumarin with bioherbicidal activity from a new strain of Lasiodiplodia pseudotheobromae C1136," Beni-Suef University Journal of Basic and Applied Sciences, vol. 7, no. 4, pp. 505-510, 2018.

[93] C. O. Adetunji, J. K. Oloke, O. M. Bello, M. Pradeep, and R. S. Jolly, "Isolation, structural elucidation, and the bioherbicidal activity of an eco-friendly bioactive 2-(hydroxymethyl) phenol, from Pseudomonas aeruginosa (C1501) and its ecotoxicological evaluation on soil," Environmental Technology \& Innovation, vol. 13, pp. 304-317, 2019.

[94] A. B. Bo, J. D. Kim, Y. S. Kim et al., "Isolation, identification, and characterization of Streptomyces metabolites as a potential bioherbicide," PLoS One, vol. 14, no. 9, pp. e0222933-e02229318, 2019.

[95] H. Zhu, Y. Ma, Q. Guo, and B. Xu, "Biological weed control using Trichoderma polysporum strain HZ-31," Crop Protection, vol. 134, Article ID 105161, 2020.

[96] F. W. Reichert Júnior, M. A. Scariot, C. T. Forte et al., "New perspectives for weeds control using autochthonous fungi with selective bioherbicide potential," Heliyon, vol. 5, no. 5, pp. e01676-6, 2019.

[97] A. Akpuaka, M. M. Ekwenchi, D. Dashak, and A. A. Dildar, "Biological activities of characterized isolates of n-hexane extract of Azadirachta indica A.Juss (neem) leaves," Natural Science, vol. 11, no. 5, pp. 141-147, 2013.

[98] A. P. Oluyori, A. K. Shaw, R. Preeti et al., "Natural antifungal compounds from the peels of Ipomoea batatas Lam," Natural Product Research, vol. 30, no. 18, pp. 2125-2129, 2016.

[99] R. Persaud, A. Khan, W.-A. Isaac, W. Ganpat, and D. Saravanakumar, "Plant extracts, bioagents, and new generation fungicides in the control of rice sheath blight in Guyana," Crop Protection, vol. 119, pp. 30-37, 2019.

[100] I. Owis, "Phytochemical and pharmacological studies of ethanolic extract of Thymus vulgaris," World J. Pharm. Phaemaceutical Sci, vol. 4, no. 10, pp. 1988-2001, 2015.

[101] C. Unuigbe, J. Enahoro, O. Erharuyi, and H. A. Okeri, "Phytochemical analysis and antioxidant evaluation of lemon grass (Cymbopogon citratus DC.) stapf leaves," Journal of Applied Sciences and Environmental Management, vol. 23, no. 2, p. 223, 2019.

[102] H. Patzke and A. Schieber, "Growth-inhibitory activity of phenolic compounds applied in an emulsifiable concentrate: ferulic acid as a natural pesticide against Botrytis cinerea," Food Research International, vol. 113, pp. 18-23, 2018.

[103] D. R. Walters, R. L. Walker, and K. C. Walker, "Lauric acid exhibits the antifungal activity against plant pathogenic fungi," Journal of Phytopathology, vol. 151, no. 4, pp. 228-230, 2003.

[104] F. Abed-ashtiani, M. Arzanlou, A. Nasehi, J. Kadir, G. Vadamalai, and S. Azadmard-Damirchi, "Plant tonic, a plant-derived bioactive natural product, exhibits the antifungal activity against rice blast disease," Industrial Crops and Products, vol. 112, pp. 105-112, 2018.

[105] B. Tang, P. Laborda, C. Sun, G. Xu, Y. Zhao, and F. Liu, "Improving the production of a novel antifungal alteramide $\mathrm{B}$ in Lysobacter enzymogenes $\mathrm{OH} 11$ by strengthening metabolic flux and precursor supply," Bioresource Technology, vol. 273, pp. 196-202, 2019.

[106] H. Dhouib, I. Zouari, D. Ben Abdallah et al., "Potential of a novel endophytic Bacillus velezensis in tomato growth promotion and protection against Verticillium wilt disease," Biological Control, vol. 139, Article ID 104092, 2019.

[107] M. Cheffi Azabou, Y. Gharbi, I. Medhioub et al., "The endophytic strain Bacillus velezensis OEE1: an efficient biocontrol agent against Verticillium wilt of olive and a potential plant growth promoting bacteria," Biological Control, vol. 142, p. 104168, July 2020.

[108] P. Patel, R. Shah, B. Joshi, K. Ramar, and A. Natarajan, "Molecular identification and biocontrol activity of sugarcane rhizosphere bacteria against red rot pathogen Colletotrichum falcatum," Biotechnology Reports, vol. 21, Article ID e00317, 2019.

[109] H. Swain, T. Adak, A. K. Mukherjee et al., "Novel Trichoderma strains isolated from tree barks as potential biocontrol agents and biofertilizers for direct seeded rice," Microbiological Research, vol. 214, pp. 83-90, 2018.

[110] R. D. Acurio Vásconez, E. M. Tenorio Moya, L. A. Collaguazo Yépez, V. P. Chiluisa-Utreras, and I. d. 1. Á. Vaca Suquillo, "Evaluation of Bacillus megaterium strain AB4 as a potential biocontrol agent of Alternaria japonica, a mycopathogen of Brassica oleracea var. italica," Biotechnology Reports, vol. 26, Article ID e00454, 2020.

[111] K. Konno, C. Hirayama, M. Nakamura et al., "Papain protects papaya trees from herbivorous insects: role of cysteine proteases in latex," The Plant Journal, vol. 37, no. 3, pp. 370-378, 2004.

[112] J. G. Scott, N. Liu, and Z. Wen, "Insect cytochromes P450: diversity, insecticide resistance, and tolerance to plant toxins," Comparative Biochemistry and Physiology Part C: Pharmacology, Toxicology and Endocrinology, vol. 121, no. 1-3, pp. 147-155, 1998.

[113] R. Larayetan, Z. S. Ololade, O. O. Ogunmola, and A. Ladokun, "Phytochemical constituents, antioxidant, cytotoxicity, antimicrobial, antitrypanosomal, and antimalarial potentials of the crude extracts of Callistemon citrinus," Evidence-Based Complementary and Alternative Medicine, vol. 2019, pp. 1-14, 2019.

[114] L. P. Ribeiro, O. Z. Zanardi, J. D. Vendramim, and P. T. Yamamoto, "Comparative toxicity of an acetogeninbased extract and commercial pesticides against citrus red mite," Experimental and Applied Acarology, vol. 64, no. 1, pp. 87-98, 2014.

[115] F. Tacoli, V. A. Bell, E. Cargnus, and F. Pavan, "Insecticidal activity of natural products against vineyard mealybugs (Hemiptera: Pseudococcidae)," Crop Protection, vol. 111, pp. 50-57, 2018.

[116] J. U. Itelima, V. C. Nwokedi, A. I. Ogbonna, and M. A. Nyam, "Phytochemical screening and the antimicrobial activity evaluation of aqueous and ethanolic extracts of the leaf of Azadirachta indica Juss (neem) on some microorganisms," World Journal of Microbiology, vol. 3, no. 1, pp. 56-60, 2016.

[117] M. A. Hossain, W. A. S. Al-toubi, A. M. Weli, Q. A. Alriyami, and J. N. Al-sabahi, "Identification and characterization of chemical compounds in different crude extracts from leaves of Omani neem," Journal of Taibah University for Science, vol. 7, no. 4, pp. 181-188, 2013.

[118] M. B. Isman, "Botanical insecticides, deterrents, and repellents in modern agriculture and an increasingly regulated 
World," Annual Review of Entomology, vol. 51, no. 1, pp. $45-66,2006$.

[119] M. F. B. Mfarrej and F. M. Rara, "Competitive, sustainable natural pesticides," Acta Ecologica Sinica, vol. 39, no. 2, pp. 145-151, 2019.

[120] A. Onekutu and L. A. Nnamonu, "Green pesticides in Nigeria: an overview," Journal of Biology, Agriculture and Healthcare, vol. 5, no. 9, pp. 48-62, 2015.

[121] A. A. Ujjan, M. Khanzada, and S. Shahzad, "Insecticide and papaya leaf extract toxicity to mustard aphid (Lipaphis erysimi Kal.)," Journal of Agri-Food and Applied Sciences, vol. 2, no. 2, pp. 45-48, 2014.

[122] S. Muzemu, J. Chitamba, and B. Mutetwa, "Evaluation of Eucalyptus tereticornis, Tagetes minuta, and Carica papaya as stored maize grain protectants against Sitophilus zeamais (Motsch.) (Coleoptera: Curculionidae)," Agriculture, Forestry and Fisheries, vol. 2, no. 5, p. 196, 2013.

[123] N. Zobayer and R. Hasan, "Effects of manually processed biopesticides on crop production and pest managements in okra (Abelmoschus esculentus (L.) Moench)," Journal of Natural Sciences Research, vol. 3, no. 8, pp. 2225-2921, 2013.

[124] Y.-P. Liu, Q. Wen, S. Hu et al., "Furanocoumarins with potential antiproliferative activities from Clausena lenis," Natural Product Research, vol. 33, no. 18, pp. 2631-2637, 2019.

[125] Z. Wu, W. Wei, K. Cheng, L. Zheng, C. Ma, and Y. Wang, "Insecticidal activity of triterpenoids and volatile oil from the stems of Tetraena mongolica," Pesticide Biochemistry and Physiology, vol. 166, Article ID 104551, 2020.

[126] K. D. Ileke, "Insecticidal toxicity of two bruchid-resistant cowpea cultivar powders as cowpea seed protectants against Callosobruchus maculatus (Fab.) (Coleoptera: Chrysomelidae)," Food Quality and Safety, vol. 3, no. 1, pp. 35-39, 2019.

[127] D. Dabas, R. Shegog, G. Ziegler, and J. Lambert, “Avocado (Persea americana) seed as a source of bioactive phytochemicals," Current Pharmaceutical Design, vol. 19, no. 34, pp. 6133-6140, 2013.

[128] E. A.-S. Shaalan, D. Canyon, M. W. F. Younes, H. AbdelWahab, and A.-H. Mansour, "A review of botanical phytochemicals with mosquitocidal potential," Environment International, vol. 31, no. 8, pp. 1149-1166, 2005.

[129] S. J. Yu, "Insecticide resistance in the fall armyworm, Spodoptera frugiperda (J. E. Smith)," Pesticide Biochemistry and Physiology, vol. 39, no. 1, pp. 84-91, 1991.

[130] E. P. Grijalba, C. Espinel, P. E. Cuartas, M. L. Chaparro, and L. F. Villamizar, "Metarhizium rileyi biopesticide to control Spodoptera frugiperda: stability and insecticidal activity under glasshouse conditions," Fungal Biology, vol. 122, no. 11, pp. 1069-1076, 2018.

[131] J.-F. Liu, Z.-Q. Zhang, J. R. Beggs, E. Paderes, X. Zou, and X.-Y. Wei, "Lethal and sublethal effects of entomopathogenic fungi on tomato/potato psyllid, Bactericera cockerelli (Sulc) (Hemiptera: triozidae) in capsicum," Crop Protection, vol. 129, Article ID 105023, 2020.

[132] P. Feng, Y. Shang, K. Cen, and C. Wang, "Fungal biosynthesis of the bibenzoquinone oosporein to evade insect immunity," Proceedings of the National Academy of Sciences, vol. 112, no. 36, pp. 11365-11370, 2015.

[133] A. A. Elbanhawy, E. A. Elsherbiny, A. E. Abd El-Mageed, and G. M. Abdel-Fattah, "Potential of fungal metabolites as a biocontrol agent against cotton aphid, Aphis gossypii Glover and the possible mechanisms of action," Pesticide Biochemistry and Physiology, vol. 159, pp. 34-40, 2019.
[134] G. H. Mariam, H. A. A. Hala, E. A. Elsherbiny, and A. M. Nofal, "Efficacy of entomopathogenic fungi Metarhizium anisopliae and cladosporium cladosporioides as biocontrol agents against two tetranychid mites (Acari: Tetranychidae)," Egyptian Journal of Biological Pest control, vol. 26, no. 2, pp. 197-201, 2016.

[135] M. Wang, L. Geng, X. Sun, C. Shu, F. Song, and J. Zhang, "Screening of Bacillus thuringiensis strains to identify new potential biocontrol agents against Sclerotinia sclerotiorum and Plutella xylostella in Brassica campestris L," Biological Control, March, vol. 145, p. 104262, 2020.

[136] J. Chen, X.-H. Yan, J.-H. Dong et al., "Tobacco mosaic virus (TMV) inhibitors from Picrasma quassioides Benn," Journal of Agricultural and Food Chemistry, vol. 57, no. 15, pp. 6590-6595, 2009.

[137] M. H. Ghodoum Parizipour and A. G. Shahriari, "Investigation of antiviral potential of licorice (Glycyrrhiza glabra L.) crude extract against tobacco mosaic virus," J. Anim. Plant Sci., vol. 30, no. 1, pp. 107-114, 2020.

[138] Q.-F. Hu, B. Zhou, J.-M. Huang et al., "Antiviral phenolic compounds from Arundina gramnifolia," Journal of Natural Products, vol. 76, no. 2, pp. 292-296, 2013.

[139] L. Zhao, J. Dong, Z. Hu et al., "Anti-TMV activity and functional mechanisms of two sesquiterpenoids isolated from Tithonia diversifolia," Pesticide Biochemistry and Physiology, vol. 140, pp. 24-29, 2017.

[140] S. Ma, X. Shi, H. Yan, Z. Ma, and X. Zhang, "Antiphytoviral activity of alkaloids from Cephalotaxus sinensis," Industrial Crops and Products, vol. 94, pp. 658-664, 2016.

[141] X. Zhang, Y. Zhou, Z. Wei et al., "Antiphytoviral toxins of Actinidia chinensis root bark (ACRB) extract: laboratory and semi-field trials," Pest Management Science, vol. 74, no. 7, pp. 1630-1636, 2018.

[142] R. Rasoulpour, A. Afsharifar, and K. Izadpanah, "Antiviral activity of prickly pear (Opuntia ficus-indica (L.) Miller) extract: Opuntin B, a second antiviral protein," Crop Protection, vol. 112, pp. 1-9, 2018.

[143] N. Petrov, M. Stoyanova, and M. Valkova, "Antiviral activity of plant extract from Tanacetum vulgare against cucumber mosaic virus and potato virus Y," Journal of Bioscience and Biotechnology, vol. 5, no. 2, pp. 189-194, 2016.

[144] R. Rasoulpour, K. Izadpanah, and A. Afsharifar, "Opuntin B, the antiviral protein isolated from prickly pear (Opuntia ficus-indica (L.) Miller) cladode exhibits the ribonuclease activity," Microbial Pathogenesis, vol. 140, Article ID 103929, 2020.

[145] S. E. Yazdi, J. Mulabisana, G. Prinsloo, M. Cloete, and Q. Kritzinger, "Plants containing cardiac glycosides showing antiphytoviral activity against potato virus Y (PVY NTN) on tobacco plants," Journal of Plant Protection Research, vol. 58, no. 4, pp. 397-403, 2018.

[146] R. A. Al-Ani, "Antiviral activity of vit-org, 2-nitromethyl phenol and thuja extract against Eggplant blister mottled virus (EBMV)," African Journal of Microbiology Research, vol. 5 , no. 21 , p. $21,2011$.

[147] A. Y. Aldhebiani, E. K. F. Elbeshehy, A. A. Baeshen, and T. Elbeaino, "Inhibitory activity of different medicinal extracts from thuja leaves, ginger roots, harmal seeds, and turmeric rhizomes against fig leaf mottle-associated virus 1 (FLMaV-1) infecting figs in Mecca region," Saudi Journal of Biological Sciences, vol. 24, no. 4, pp. 936-944, 2017.

[148] E. K. F. Elbeshehy, E. M. R. Metwali, and O. A. Almaghrabi, "Antiviral activity of thuja orientalis extracts against watermelon mosaic virus (WMV) on Citrullus lanatus," Saudi 
Journal of Biological Sciences, vol. 22, no. 2, pp. 211-219, 2015.

[149] E. K. F. Elbeshehy, "Inhibitor activity of different medicinal plants extracts from thuja orientalis, Nigella sativa L., Azadirachta indica, and Bougainvillea spectabilis against zucchini yellow mosaic virus (ZYMV) infecting Citrullus lanatus," Biotechnology \& Biotechnological Equipment, vol. 31, no. 2, pp. 270-279, 2017.

[150] J. Cong and B. Lin, "Separation of liquiritin by simulated moving bed chromatography," Journal of Chromatography A, vol. 1145, no. 1-2, pp. 190-194, 2007.

[151] L. G. Houessou, T. O. Lougbegnon, F. G. Gbesso, L. E. Anagonou, and B. Sinsin, "Ethno-botanical study of the African star apple (Chrysophyllum albidum G. Don) in the Southern Benin (West Africa)," Journal of Ethnobiology and Ethnomedicine, vol. 8, p. 401, 2012.

[152] P. Srivastava, P. Kumar, D. K. Singh, and V. K. Singh, "Biological properties of Thuja orientalis Linn," Advances in Life Sciences, vol. 2, no. 2, pp. 17-20, 2012.

[153] S. Vinodkumar, S. Nakkeeran, P. Renukadevi, and S. Mohankumar, "Diversity and antiviral potential of rhizospheric and endophytic Bacillus species and phyto-antiviral principles against tobacco streak virus in cotton," Agriculture, Ecosystems \& Environment, vol. 267, pp. 42-51, 2018.

[154] G. H. Lee and C.-M. Ryu, "Spraying of leaf-colonizing Bacillus amyloliquefaciens protects pepper from cucumber mosaic virus," Plant Disease, vol. 100, no. 10, pp. 2099-2105, 2016.

[155] S. M. Ryu, J. Kwon, Y. H. Seo et al., "Quassinoids isolated from Brucea javanica inhibit pepper mottle virus in pepper," Virus Research, vol. 227, pp. 49-56, 2017.

[156] Y. Han, Y. Luo, S. Qin, L. Xi, B. Wan, and L. Du, "Induction of systemic resistance against tobacco mosaic virus by ningnanmycin in tobacco," Pesticide Biochemistry and Physiology, vol. 111, no. 1, pp. 14-18, 2014.

[157] L. Yu, W. Wang, S. Zeng et al., "Label-free quantitative proteomics analysis of Cytosinpeptidemycin responses in southern rice black-streaked dwarf virus-infected rice," Pesticide Biochemistry and Physiology, vol. 147, pp. 20-26, 2018.

[158] S. K. Mirza, U. K. Asema, and S. Kasim, "To study the harmful effects of food preservatives on human health," Journal of Medicinal Chemistry and Drug Design, vol. 2, no. 2347-9027, pp. 610-616, 2017.

[159] K. Zelman, "The vital role of food preservatives," Food \& Nutrition, 2018.

[160] M. Pal, A. Gebretensay, T. Shiberu, M. Abdurahman, and O. Karanfil, "The role of bacteriosin as food preservative," Beverage Food World, vol. 42, no. 34, pp. 28-31, 2015.

[161] R. Talon and M. Zagorec, "Special issue: beneficial microorganisms for food manufacturing-fermented and biopreserved foods and beverages," Microorganisms, vol. 5, no. 4, pp. 71-11, 2017.

[162] I. S. Arvanitoyannis, C. Palaiokostas, and P. Panagiotaki, "A comparative presentation of implementation of ISO 22000 versus HACCP and FMEA in a small size Greek factory producing smoked trout: a case study," Critical Reviews in Food Science and Nutrition, vol. 49, no. 2, pp. 176-201, 2009.

[163] P. Loaharanu and M. Ahmed, "Advantages and disadvantages of the use of irradiation for food preservation," Journal of Agricultural and Environmental Ethics, vol. 4, no. 1, pp. 14-30, 1991.
[164] H. Ahari, S. Mahyar, and H. Fathollahi, "The potential of food irradiation: benefits and limitations," in Trends in Vital Food and Control Engineering, A. H. A. Eissa (Ed)., IntechOpen, London, UK, 2012.

[165] D. Samal, S. Gouda, and J. Patra, "Food preservatives and their uses: a short report," Asian Journal of Biology, vol. 4, no. 1, pp. 1-4, 2017.

[166] S. Sharma, "Food preservative and their harmful effects," International Journal of Scientific and Research Publication, vol. 5, no. 4, pp. 1-2, 2015.

[167] A. Roy, O. Bulut, S. Some, A. K. Mandal, and M. D. Yilmaz, "Green synthesis of silver nanoparticles: biomoleculenanoparticle organizations targeting the antimicrobial activity," RSC Advances, vol. 9, no. 5, pp. 2673-2702, 2019.

[168] H. Kumar, A. Kumar Jha, K. K. Taneja, K. Kabra, and H. M. Sadiq, "A study on consumer awareness, safety perceptions and practices about food preservatives and flavouring agents used in packed/canned foods from south India," National Journal of Community Medicine, vol. 4, no. 3, p. 3, 2013, http://www.njcmindia.org.

[169] IARC (Internation Agency for Research on Cancer), "World health organization international agency for research on cancer," IARC Monographs on the Evaluation of Carcinogenic Risks to Humans, vol. 94, pp. 1-464, 2010.

[170] C. Ayres, "5 advantages and disadvantages of fermented foods," ConnectUS, https://connectusfund.org/5-advantagesand-disadvantages-of-fermented-foods, March 2020.

[171] J. Kim, M. Kang, J.-S. Lee, M. Inoue, S. Sasazuki, and S. Tsugane, "Fermented and nonfermented soy food consumption and gastric cancer in Japanese and Korean populations: a meta-analysis of observational studies," Cancer Science, vol. 102, no. 1, pp. 231-244, 2011.

[172] C. Art, "The advantages and disadvantages of freezing food," The Journal, https://www.journal-news.net/life/food/theadvantages-and-disadvantages-of-freezing-food/article 8194db89-6214-5848-b5ba-11adf877db38.html, March 2020.

[173] EFSA, "Scientific opinion on the reevaluation of sorbic acid (E 200), potassium sorbate (E 202) and calcium sorbate (E 203) as food additives," EFSA Journal, vol. 13, no. 6, pp. 1-91, 2016.

[174] M. Aziz and S. Karboune, "Natural antimicrobial/antioxidant agents in meat and poultry products as well as fruits and vegetables: a review," Critical Reviews in Food Science and Nutrition, vol. 58, no. 3, pp. 1-26, 2018.

[175] N. Ahmed, J. Singh, H. Kour, and P. Gupta, "Naturally occurring preservatives in food and their role in food preservation," International Journal of Pharmaceutical \& Biological Archive, vol. 4, no. 1, pp. 22-30, 2013.

[176] M. O. Faruque, U. R. Ankhi, M. Kamaruzzaman et al., "Chemical composition and antimicrobial activity of Congea tomentosa, an ethnomedicinal plant from Bangladesh," Industrial Crops and Products, vol. 141, p. 111745, 2019.

[177] S. Mohotti, S. Rajendran, T. Muhammad et al., "Screening for bioactive secondary metabolites in Sri Lankan medicinal plants by microfractionation and targeted isolation of antimicrobial flavonoids from Derris scandens," Journal of Ethnopharmacology, vol. 246, p. 112158, 2020.

[178] C. P. Boeira, N. Piovesan, D. C. B. Flores et al., "Phytochemical characterization and antimicrobial activity of Cymbopogon citratus extract for application as natural antioxidant in fresh sausage," Food Chemistry, vol. 319, p. $126553,2020$. 
[179] V. M. L. Naves, M. H. dos Santos, I. S. Ribeiro et al., "Antimicrobial and antioxidant activity of Garcinia brasiliensis extracts," South African Journal of Botany, vol. 124, pp. 244-250, 2019.

[180] A. A. Tayel, S. M. Shaban, S. H. Moussa et al., "Bioactivity and application of plant seeds' extracts to fight resistant strains of Staphylococcus aureus," Annals of Agricultural Sciences, vol. 63, no. 1, pp. 47-53, 2018.

[181] L. Tamkutè, B. M. Gil, J. R. Carballido, M. Pukalskienè, and P. R. Venskutonis, "Effect of cranberry pomace extracts isolated by pressurized ethanol and water on the inhibition of food pathogenic/spoilage bacteria and the quality of pork products," Food Research International, vol. 120, pp. 38-51, 2019.

[182] N. O. Egbuonu, C. Anthony, I. C. Opara, C. Onyeabo, and Uchenna, "Proximate, functional, antinutrient, and antimicrobial properties of avocado pear (Persea americana) seeds," Journal of Nutritional Health \& Food Engineering, vol. 8, no. 1, pp. 78-82, 2018.

[183] Y. Yang, H. Chen, J. Lei, and J. Yu, "Biological activity of extracts and active compounds isolated from Siegesbeckia orientalis L," Industrial Crops and Products, vol. 94, pp. 288-293, 2016.

[184] S. L. Oputah, K. O. Ajanaku, R. C. Mordi, and J. A. O. Olugbuyiro, "Phytochemical and antibacterial properties of ethanolic seed extracts of chrysophyllum albidum," Oriental Journal of Physical Sciences, vol. 1, no. 1, 2016.

[185] C. Kahraman, G. Topcu, E. Bedir, I. I. Tatli, M. Ekizoglu, and Z. S. Akdemir, "Phytochemical screening and evaluation of the antimicrobial and antioxidant activities of Ferula caspica M. Bieb. extracts," Saudi Pharmaceutical Journal, vol. 27, no. 4, pp. 525-531, 2019.

[186] S. L. Sukanya, J. Sudisha, P. Hariprasad, S. R. Niranjana, H. S. Prakash, and S. K. Fathima, "Antimicrobial activity of leaf extracts of Indian medicinal plants against clinical and phytopathogenic bacteria," African Journal of Biotechnology, vol. 8, no. 23, pp. 6677-6682, 2009.

[187] R. Palmeri, L. Parafati, C. Restuccia, and B. Fallico, "Application of prickly pear fruit extract to improve domestic shelf life, quality, and microbial safety of sliced beef," Food and Chemical Toxicology, vol. 118, pp. 355-360, 2018.

[188] H. Degirmenci and H. Erkurt, "Chemical profile and antioxidant potency of Citrus $\times$ aurantium L. flower extracts with the antibacterial effect against foodborne pathogens in rice pudding," LWT, vol. 126, Article ID 109273, 2020.

[189] B. Oliveira de Veras, M. B. Melo de Oliveira, F. Granja da Silva Oliveira et al., "Chemical composition and evaluation of the antinociceptive, antioxidant, and antimicrobial effects of essential oil from Hymenaea cangaceira (Pinto, Mansano, and Azevedo) native to Brazil: a natural medicine," Journal of Ethnopharmacology, vol. 247, Article ID 112265, 2020.

[190] J. P. C. d. Vale, L. H. d. F. Ribeiro, M. A. d. Vasconcelos et al., "Chemical composition, antioxidant, antimicrobial, and antibiofilm activities of Vitex gardneriana schauer leaves's essential oil," Microbial Pathogenesis, vol. 135, Article ID 103608, 2019.

[191] W. Zhou, Y. He, X. Lei et al., "Chemical composition and evaluation of antioxidant activities, antimicrobial, and antimelanogenesis effect of the essential oils extracted from Dalbergia pinnata (Lour.) Prain," Journal of Ethnopharmacology, vol. 254, Article ID 112731, 2020.

[192] K. Hąc-Wydro, M. Flasiński, and K. Romańczuk, "Essential oils as food ecopreservatives: model system studies on the effect of temperature on the limonene antibacterial activity," Food Chemistry, vol. 235, pp. 127-135, 2017.

[193] F. Yi, R. Jin, J. Sun, B. Ma, and X. Bao, "Evaluation of mechanical-pressed essential oil from Nanfeng mandarin (Citrus reticulata Blanco cv. Kinokuni) as a food preservative based on antimicrobial and antioxidant activities," $L W T$, vol. 95, pp. 346-353, 2018.

[194] M. V. Arasu, P. Viayaraghavan, S. Ilavenil, N. A. Al-Dhabi, and K. C. Choi, "Essential oil of four medicinal plants and protective properties in plum fruits against the spoilage bacteria and fungi," Industrial Crops and Products, vol. 133, pp. 54-62, 2019.

[195] T. A. Ibrahim, A. M. Salama, and E. B. Zahran, "Antimicrobial efficacy of moringa seed extracts against some postharvest disease pathogens of tomato," Gezira Journal of Agricultural Science, vol. 17, no. 1, pp. 1-15, 2019.

[196] N. O. Olaleye, A. M. Omotayo, O. A. Olanlege, and O. A. Longe, "Shelf life extension of tomato (Lycopersicum esculentum) and pepper (Capsicum annuum) using aqueous extracts of some ethnomedicinal plants," Journal of Agriculture, Science and Technology A, vol. 4, pp. 806-810, 2014.

[197] A. Moshari-Nasirkandi, A. Alirezalu, and M. A. Hachesu, "Effect of lemon verbena bioextract on phytochemical and antioxidant capacity of strawberry (Fragaria $\times a n a n a s s a$ Duch. cv. Sabrina) fruit during cold storage," Biocatalysis and Agricultural Biotechnology, vol. 25, Article ID 101613, 2020.

[198] J. H. Choi, J.-Y. Kim, E. T. Jeong, T. H. Choi, and T. M. Yoon, "Preservative effect of Camellia sinensis (L.) Kuntze seed extract in soy sauce and its mutagenicity," Food Research International, vol. 105, pp. 982-988, 2018.

[199] M. V. Fernandez, M. Bengardino, R. J. Jagus, and M. V. Agüero, "Enrichment and preservation of a vegetable smoothie with an antioxidant and antimicrobial extract obtained from beet by-products," LWT, vol. 117, p. 108622, 2020.

[200] S. Akhila and N. G. Vijayalakshmi, "Phytochemical studies on Carica papaya leaf juice," International Journal of Pharmaceutical Sciences and Research, vol. 6, no. 2, pp. $880-883,2015$.

[201] C. U. Aguoru, C. Pilla, and J. O. Olasan, "Phytochemical screening of Xylopia aethiopica with emphasis on its medicinally active principles," Journal of. Medicinal Plants Research, vol. 10, no. 22, pp. 306-309, 2016.

[202] L. Wei, J. Zhao, Y. Meng, Y. Guo, and C. Luo, “Antibacterial activity, safety, and preservative effect of aminoethylphloretin on the quality parameters of salmon fillets," $L W T$, vol. 118, Article ID 108874, 2020.

[203] C. Soumya, M. L. Sudha, M. Vijaykrishnaraj, P. S. Negi, and P. Prabhasankar, "Comparative study on batter, quality characteristics, and storage stability of muffins using natural ingredients (preservatives) and synthetic preservatives," Journal of Food Processing and Preservation, vol. 41, no. 6, pp. e13242-e13249, 2017.

[204] A. Ribeiro, L. Barros, R. C. Calhelha et al., "Tarragon phenolic extract as a functional ingredient for pizza dough: comparative performance with ascorbic acid (E300)," Journal of Functional Foods, vol. 26, pp. 268-278, 2016.

[205] R. Montiel, I. Martín-Cabrejas, and M. Medina, "Reuterin, lactoperoxidase, lactoferrin, and high hydrostatic pressure on the inactivation of foodborne pathogens in cooked ham," Food Control, vol. 51, pp. 122-128, 2015.

[206] C. Luz, F. Saladino, F. B. Luciano, J. Mañes, and G. Meca, "In vitro antifungal activity of bioactive peptides produced by 
Lactobacillus plantarum against Aspergillus parasiticus and Penicillium expansum," LWT-Food Science and Technology, vol. 81, pp. 128-135, 2017.

[207] H. Sedaghat, M. H. Eskandari, M. Moosavi-nasab, and S. S. Shekarforoush, "Application of nonstarter lactic acid bacteria as biopreservative agents to control fungal spoilage of fresh cheese," International Dairy Journal, vol. 56, pp. 87-91, 2016.

[208] A. A. Tayel, "Microbial chitosan as a biopreservative for fish sausages," International Journal of Biological Macromolecules, vol. 93, pp. 41-46, 2016.

[209] L. I. Schelegueda, M. Vallejo, M. F. Gliemmo, E. R. Marguet, and C. A. Campos, "Synergistic antimicrobial action and potential application for fish preservation of a bacteriocin produced by Enterococcus mundtii isolated from Odontesthes platensis," LWT-Food Science and Technology, vol. 64, no. 2, pp. 794-801, 2015.

[210] T. Wu, X. Zang, M. He, S. Pan, and X. Xu, "Structure-Activity relationship of flavonoids on their anti-Escherichia coli activity and inhibition of DNA gyrase," Journal of Agricultural and Food Chemistry, vol. 61, no. 34, pp. 81858190, 2013.

[211] M. Takó, E. B. Kerekes, C. Zambrano et al., "Plant phenolics and phenolic-enriched extracts as antimicrobial agents against food-contaminating microorganisms," Antioxidants, vol. 9, no. 2, pp. 165-186, 2020.

[212] T. Tayengwa, O. C. Chikwanha, P. Gouws, M. E. R. Dugan, T. Mutsvangwa, and C. Mapiye, "Dietary citrus pulp and grape pomace as potential natural preservatives for extending beef shelf life," Meat Science, vol. 162, Article ID 108029, 2020.

[213] Y. Zhao, M. Chen, Z. Zhao, and S. Yu, "The antibiotic activity and mechanisms of sugarcane (Saccharum officinarum L.) bagasse extract against foodborne pathogens," Food Chemistry, vol. 185, pp. 112-118, 2015.

[214] I. Borrás-Linares, S. Fernández-Arroyo, D. Arráez-Roman et al., "Characterization of phenolic compounds, anthocyanidin, antioxidant, and antimicrobial activity of 25 varieties of Mexican Roselle (Hibiscus sabdariffa)," Industrial Crops and Products, vol. 69, pp. 385-394, 2015.

[215] Y. Wu, J. Bai, K. Zhong et al., "Antibacterial activity and membrane-disruptive mechanism of 3-p-trans-coumaroyl2-hydroxyquinic acid, a novel phenolic compound from pine needles of Cedrus deodara, against Staphylococcus aureus," Molecules, vol. 21, no. 8, p. 1084, 2016.

[216] Y. Wu, J. Bai, X. Liu et al., "Antibacterial effect of 3-p-transcoumaroyl-2-hydroxyquinic acid, a phenolic compound from needles of Cedrus deodara, on cellular functions of Staphylococcus aureus," RSC Advances, vol. 8, no. 9, pp. 4969-4975, 2018.

[217] Y. Wu, J. Bai, K. Zhong, Y. Huang, and H. Gao, “A dual antibacterial mechanism involved in membrane disruption and DNA binding of 2R, 3R-dihydromyricetin from pine needles of Cedrus deodara against Staphylococcus aureus," Food Chemistry, vol. 218, pp. 463-470, 2017.

[218] C. Zambrano, E. B. Kerekes, A. Kotogán et al., “Antimicrobial activity of grape, apple, and pitahaya residue extracts after carbohydrase treatment against food-related bacteria," LWT, vol. 100, pp. 416-425, 2019.

[219] C. A. Elkins and L. B. Mullis, "Mammalian steroid hormones are substrates for the major RND- and MFS-type tripartite multidrug efflux pumps of Escherichia coli," Journal of Bacteriology, vol. 188, no. 3, pp. 1191-1195, 2006.
[220] N. Vida, H. Svobodová, L. Rárová et al., "Polyamine conjugates of stigmasterol," Steroids, vol. 77, no. 12, pp. 1212-1218, 2012.

[221] H. N. Matsuura and A. G. Fett-Neto, "Plant alkaloids: main features, toxicity, and mechanisms of action," in Plant Toxins, P. Gopalakrishnakone, C. Carlini, and R. LigabueBraun, Eds., pp. 1-15, Springer, Dordrecht, Netherlands, 2017.

[222] B. Moyo, P. J. Masika, and V. Muchenje, "Antimicrobial activities of Moringa oleifera Lam leaf extracts," African Journal of Biotechnology, vol. 11, no. 11, pp. 2797-2802, 2012.

[223] M. I. Khan, A. Ahhmed, J. H. Shin, J. S. Baek, M. Y. Kim, and J. D. Kim, "Green tea seed isolated saponins exerts antibacterial effects against various strains of Gram-positive and Gram-negative bacteria, a comprehensive study in vitro and in vivo," Evidence-Based Complementary and Alternative Medicine, vol. 2018, pp. 1-12, 2018.

[224] J. H. Kim, S. Y. Han, J. H. Kwon, and D. S. Lee, "Orostachys japonicus ethyl acetate fraction suppresses MRSA biofilm formation," Asian Pacific Journal of Tropical Medicine, vol. 13, no. 1, pp. $38-45,2020$.

[225] E. S. Challaraj Emmanuel, V. Biji, and G. N. Krishna, "A characteristic study on the effect of ginger and nutmeg extracts on Pseudomonas and E.coli biofilms," International Journal of Research in Pharmaceutical Sciences, vol. 11, no. 1, pp. 386-396, 2020.

[226] A. Ourabah, D. Atmani-Kilani, N. Debbache-Benaida et al., "Anti-Candida albicans biofilm activity of extracts from two selected indigenous Algerian plants: Clematis flammula and Fraxinus angustifolia," Journal of Herbal Medicine, vol. 20, p. 100319, 2020.

[227] H. Cui, C. Zhang, C. Li, and L. Lin, "Inhibition mechanism of cardamom essential oil on methicillin-resistant Staphylococcus aureus biofilm," LWT, vol. 122, p. 109057, October 2020.

[228] A. K. Farha, Q.-Q. Yang, G. Kim et al., "Inhibition of multidrug-resistant foodborne Staphylococcus aureus biofilms by a natural terpenoid (+)-nootkatone and related molecular mechanism," Food Control, vol. 112, Article ID 107154, 2020.

[229] A. M. Shehabeldine, R. M. Ashour, M. M. Okba, and F. R. Saber, "Callistemon citrinus bioactive metabolites as new inhibitors of methicillin-resistant Staphylococcus aureus biofilm formation," Journal of Ethnopharmacology, vol. 254, Article ID 112669, 2020.

[230] C. Contini, M. G. Katsikogianni, F. T. O’Neill, M. O’Sullivan, D. P. Dowling, and F. J. Monahan, "Mechanism of action of an antioxidant active packaging prepared with citrus extract," LWT-Food Science and Technology, vol. 59, no. 2, pp. 1082-1087, 2014.

[231] I. K. Kalem, Z. F. Bhat, S. Kumar, and A. Desai, “Terminalia arjuna: a novel natural preservative for improved lipid oxidative stability and storage quality of muscle foods," Food Science and Human Wellness, vol. 6, no. 4, pp. 167-175, 2017.

[232] S. Mallek-Ayadi, N. Bahloul, and N. Kechaou, "Phytochemical profile, nutraceutical potential, and functional properties of Cucumis melo L. seeds," Journal of the Science of Food and Agriculture, vol. 99, no. 3, pp. 1294-1301, 2019.

[233] S. Ali, S. Chatha, A. I. Hussain, R. Asad, M. Majeed, and N. Aslam, "Bioactive components and antioxidant properties of Terminalia arjuna L. Extracts," Journal of Food Processing and Technology, vol. 5, no. 2, pp. 298-302, 2014.

[234] S. S. Bhujbal, R. K. Nanda, R. S. Deoda et al., "Structure elucidation of a flavonoid glycoside from the roots of 
Clerodendrum serratum (L.) Moon, Lamiaceae," Revista Brasileira de Farmacognosia, vol. 20, no. 6, pp. 1001-1002, 2010.

[235] S. Khadem and R. J. Marles, "Monocyclic phenolic acids, hydroxy-, and polyhydroxybenzoic acids: occurrence and recent bioactivity studies," Molecules, vol. 15, no. 11, pp. 7985-8005, 2010.

[236] I. Jabri-Karoui, I. Bettaieb, K. Msaada, M. Hammami, and B. Marzouk, "Research on the phenolic compounds and antioxidant activities of Tunisian Thymus capitatus," Journal of Functional Foods, vol. 4, no. 3, pp. 661-669, 2012.

[237] T. K. Mendy, A. Misran, T. M. M. Mahmud, and S. I. Ismail, "Application of Aloe vera coating delays ripening and extend the shelf life of papaya fruit," Scientia Horticulturae, vol. 246, pp. 769-776, 2019.

[238] H. Hassanpour, "Effect of Aloe vera gel coating on antioxidant capacity, antioxidant enzyme activities, and decay in raspberry fruit," LWT-Food Science and Technology, vol. 60, no. 1, pp. 495-501, 2015.

[239] G. Khaliq, M. Ramzan, and A. H. Baloch, "Effect of Aloe vera gel coating enriched with Fagonia indica plant extract on physicochemical and antioxidant activity of sapodilla fruit during postharvest storage," Food Chemistry, vol. 286, pp. 346-353, 2019.

[240] K. Lorenc-Kukuła, S. Jafra, S. Oszmiański, and J. Szopa, "Ectopic expression of anthocyanin 5-O-glucosyltransferase in potato tuber causes increased resistance to bacteria," Journal of Agricultural and Food Chemistry, vol. 53, no. 2, pp. 272-281, 2005.

[241] Y. Zhang, E. Butelli, R. De Stefano et al., "Anthocyanins double the shelf life of tomatoes by delaying overripening and reducing susceptibility to gray mold," Current Biology, vol. 23, no. 12, pp. 1094-1100, 2013.

[242] T. Tsuda, F. Horio, K. Uchida, H. Aoki, and T. Osawa, "Dietary cyanidin 3-O- $\beta$-D-glucoside-rich purple corn color prevents obesity and ameliorates hyperglycemia in mice," The Journal of Nutrition, vol. 133, no. 7, pp. 2125-2130, 2003.

[243] L.-S. Wang and G. D. Stoner, "Anthocyanins and their role in cancer prevention," Cancer Letters, vol. 269, no. 2, pp. 281-290, 2008.

[244] A. P. Oluyori, A. K. Shaw, G. A. Olatunji et al., "Sweet potato peels and cancer prevention," Nutrition and Cancer, vol. 68, no. 8, pp. 1330-1337, 2016.

[245] K. Dastmalchi, I. Wang, and R. E. Stark, "Potato woundhealing tissues: a rich source of natural antioxidant molecules with potential for food preservation," Food Chemistry, vol. 210, pp. 473-480, 2016.

[246] C. Caleja, L. Barros, A. L. Antonio, M. Carocho, M. B. P. P. Oliveira, and I. C. F. R. Ferreira, "Fortification of yogurts with different antioxidant preservatives: a comparative study between natural and synthetic additives," Food Chemistry, vol. 210, pp. 262-268, 2016.

[247] C. Caleja, L. Barros, A. L. Antonio, M. B. P. P. Oliveira, and I. C. F. R. Ferreira, "A comparative study between natural and synthetic antioxidants: evaluation of their performance after incorporation into biscuits," Food Chemistry, vol. 216, pp. 342-346, 2017.

[248] U. Gawlik-Dziki, M. Świeca, D. Dziki et al., "Lipoxygenase inhibitors and antioxidants from green coffee-mechanism of action in the light of potential bioaccessibility," Food Research International, vol. 61, pp. 48-55, 2014.

[249] O. L. Erukainure, O. F. Onifade, B. O. Odjobo et al., "Ethanol extract of Tetrapleura tetraptera fruit peels: chemical characterization and antioxidant potentials against free radicals and lipid peroxidation in hepatic tissues," Journal of Taibah University for Science, vol. 11, no. 6, pp. 861-867, 2017.

[250] X.-N. Yang, I. Khan, and S. C. Kang, "Chemical composition, mechanism of antibacterial action, and antioxidant activity of leaf essential oil of Forsythia koreana deciduous shrub," Asian Pacific Journal of Tropical Medicine, vol. 8, no. 9, pp. 694-700, 2015.

[251] J. O. Olugbodi, M. B. Tincho, O. O. Oguntibeju, M. T. Olaleye, and A. C. Akinmoladun, "Glyphaea brevis: in vitro antioxidant and in silico biological activity of major constituents and molecular docking analyses," Toxicology in Vitro, vol. 59, pp. 187-196, 2019.

[252] A. Thouri, H. Chahdoura, A. El Arem, A. Omri Hichri, R. Ben Hassin, and L. Achour, "Effect of solvents extraction on phytochemical components and biological activities of Tunisian date seeds (var. Korkobbi and Arechti)," BMC Complementary and Alternative Medicine, vol. 17, no. 1, pp. 1-10, 2017.

[253] L. Gali and F. Bedjou, "Antioxidant and anticholinesterase effects of the ethanol extract, ethanol extract fractions, and total alkaloids from the cultivated Ruta chalepensis," South African Journal of Botany, vol. 120, pp. 163-169, 2019.

[254] D. Pergher, A. Picolotto, P. F. Rosales et al., “Antinociceptive and antioxidant effects of extract enriched with active indole alkaloids from leaves of Tabernaemontana catharinensis A. DC," Journal of Ethnopharmacology, vol. 239, p. 111863, 2019.

[255] S. Khamtache-Abderrahim, M. Lequart-Pillon, E. Gontier et al., "Isoquinoline alkaloid fractions of Fumaria officinalis: characterization and evaluation of their antioxidant and antibacterial activities," Industrial Crops and Products, vol. 94, pp. 1001-1008, 2016.

[256] K. Malczewska-Jaskóła, B. Jasiewicz, and L. Mrówczyńska, "Nicotine alkaloids as antioxidant and potential protective agents against in vitro oxidative haemolysis," Chemico-Biological Interactions, vol. 243, pp. 62-71, 2016.

[257] S. Liu, T. Yang, T. W. Ming et al., "Isosteroid alkaloids from Fritillaria cirrhosa bulbus as inhibitors of cigarette smokeinduced oxidative stress," Fitoterapia, vol. 140, Article ID 104434, 2020

[258] A. A. Gomaa, R. M. Makboul, M. A. El-Mokhtar, E. A. Abdel-Rahman, I. A. Ahmed, and M. A. Nicola, "Terpenoid-rich Elettaria cardamomum extract prevents Alzheimer-like alterations induced in diabetic rats via inhibition of the GSK3 $\beta$ activity, oxidative stress, and proinflammatory cytokines," Cytokine, vol. 113, pp. 405-416, 2019.

[259] R. M. P. Brandão-Costa, T. Pajeu Nascimento, R. Pedrosa Bezerra, and A. L. F. Porto, "FDS, FDS, a novel saponin isolated from Felicium decipiens: lectin interaction and biological complementary activities," Process Biochemistry, vol. 88, pp. 159-169, 2020.

[260] L. K. Nzowa, L. Barboni, R. B. Teponno et al., "Rheediinosides A and B, two antiproliferative and antioxidant triterpene saponins from Entada rheedii," Phytochemistry, vol. 71, no. 2-3, pp. 254-261, 2010.

[261] I. Dini, G. C. Tenore, and A. Dini, "Saponins in Ipomoea batatas tubers: isolation, characterization, quantification, and antioxidant properties," Food Chemistry, vol. 113, no. 2, pp. 411-419, 2009.

[262] G. Zengin, A. Cvetanović, U. Gašić et al., "A comparative exploration of the phytochemical profiles and biopharmaceutical potential of Helichrysum stoechas subsp. barrelieri extracts obtained via five extraction techniques," Process Biochemistry, vol. 91, pp. 113-125, 2020. 
[263] B. Sik, E. L. Hanczné, V. Kapcsándi, and Z. Ajtony, “Conventional and nonconventional extraction techniques for optimal extraction processes of rosmarinic acid from six Lamiaceae plants as determined by HPLC-DAD measurement," Journal of Pharmaceutical and Biomedical Analysis, vol. 184, p. 113173, 2020.

[264] G. Zengin, A. Cvetanović, U. Gašić et al., "Modern and traditional extraction techniques affect chemical composition and bioactivity of Tanacetum parthenium (L.) Sch. Bip," Industrial Crops and Products, vol. 146, p. 112202, 2020.

[265] M. Senica, F. Stampar, S. Ercisli, B. Sladonja, D. Poljuha, and M. Mikulic-Petkovsek, "The impact of drying on bioactive compounds of blue honeysuckle berries (Lonicera caerulea var. edulis Turcz. ex Herder)," Acta Botanica Croatica, vol. 79, no. 1, pp. 68-77, 2020.

[266] G. Alvarez-Rivera, M. Bueno, D. Ballesteros-Vivas, J. A. Mendiola, and E. Ibañez, "Pressurized liquid extraction," in Liquid-Phase Extraction, pp. 375-398, Elsevier, Amsterdam, Netherlands, 2020.

[267] M. Solana, I. Boschiero, S. Dall'Acqua, and A. Bertucco, "Extraction of bioactive enriched fractions from Eruca sativa leaves by supercritical $\mathrm{CO}_{2}$ technology using different cosolvents," The Journal of Supercritical Fluids, vol. 94, pp. 245-251, 2014.

[268] G. Zhang, L. He, and M. Hu, "Optimized ultrasonic-assisted extraction of flavonoids from Prunella vulgaris L. and evaluation of antioxidant activities in vitro," Innovative Food Science \& Emerging Technologies, vol. 12, no. 1, pp. 18-25, 2011.

[269] H. Salehi, M. Karimi, N. Rezaie, and F. Raofie, "Extraction of $\beta$-carboline alkaloids and preparation of extract nanoparticles from Peganum harmala L. capsules using supercritical fluid technique," Journal of Drug Delivery Science and Technology, vol. 56, Article ID 101515, 2020.

[270] S. S. Takla, E. Shawky, H. M. Hammoda, and F. A. Darwish, "Green techniques in comparison to conventional ones in the extraction of Amaryllidaceae alkaloids: best solvents selection and parameters optimization," Journal of Chromatography A, vol. 1567, pp. 99-110, 2018.

[271] P. U. Amadi, E. N. Agomuo, A. I. Bob-Chile Agada et al., "Toxicities of selected medicinal plants and floras of lower phyla," Alexandria Journal of Medicine, vol. 54, no. 4, pp. 587-596, 2018.

[272] M. B. Adekola, J. O. Areola, N. O. Omisore et al., "Subchronic toxicity study of ethanol stem-bark extract of Blighia sapida (Sapindaceae) in wistar rats," Heliyon, vol. 6, no. 2, Article ID e02801, 2020.

[273] L. Ory, E.-H. Nazih, S. Daoud et al., "Targeting bioactive compounds in natural extracts: development of a comprehensive workflow combining chemical and biological data," Analytica Chimica Acta, vol. 1070, pp. 29-42, 2019.

[274] S. Roehrer, J. Behr, V. Stork et al., "Xanthohumol C, a minor bioactive hop compound: production, purification strategies, and antimicrobial test," Journal of Chromatography $B$, vol. 1095, pp. 39-49, 2018.

[275] M.-H. Lee, J.-H. Jeong, J.-W. Seo et al., "Enhanced triterpene and phytosterol biosynthesis in Panax ginseng overexpressing squalene synthase gene," Plant and Cell Physiology, vol. 45, no. 8, pp. 976-984, 2004.

[276] A. Orts, E. Revilla, B. Rodriguez-Morgado et al., "Protease technology for obtaining a soy pulp extract enriched in bioactive compounds: isoflavones and peptides," Heliyon, vol. 5, no. 6, Article ID e01958, 2019.
[277] Z. Y. Hosea, K. Liamngee, A. L. Owoicho, and T. David, "Effect of neem leaf powder on postharvest shelf life and quality of tomato fruits in storage," International Journal of Sustainable Development, vol. 6, no. 10, pp. 1334-1349, 2017.

[278] P. Bora, S. Ragaee, and E.-S. M. Abdel-Aal, "Effect of incorporation of goji berry by-product on biochemical, physical, and sensory properties of selected bakery products," LWT, vol. 112, Article ID 108225, 2019.

[279] G. Liguori, C. Gentile, R. Gaglio et al., "Effect of addition of Opuntia ficus-indica mucilage on the biological leavening, physical, nutritional, antioxidant, and sensory aspects of bread," Journal of Bioscience and Bioengineering, vol. 129, no. 2, pp. 184-191, 2020.

[280] L. Gao, Q. Li, Y. Zhao et al., "Silver nanoparticles biologically synthesised using tea leaf extracts and their use for extension of fruit shelf life," IET Nanobiotechnology, vol. 11, no. 6, pp. 637-643, 2017.

[281] M. M. I. Masum, M. M. Siddiqa, K. A. Ali et al., "Biogenic synthesis of silver nanoparticles using Phyllanthus emblica fruit extract and its inhibitory action against the pathogen Acidovorax oryzae strain RS-2 of rice bacterial brown stripe," Frontiers in Microbiology, vol. 10, pp. 1-18, 2019.

[282] M. Carbone, D. T. Donia, G. Sabbatella, and R. Antiochia, "Silver nanoparticles in polymeric matrices for fresh food packaging," Journal of King Saud University-Science, vol. 28, no. 4, pp. 273-279, 2016.

[283] I. Khan, K. Saeed, and I. Khan, "Nanoparticles: properties, applications, and toxicities," Arabian Journal of Chemistry, vol. 12, no. 7, pp. 908-931, 2019.

[284] S. Ahmed, M. Ahmad, B. L. Swami, and S. Ikram, "A review on plants extract mediated synthesis of silver nanoparticles for antimicrobial applications: a green expertise," Journal of Advanced Research, vol. 7, no. 1, pp. 17-28, 2016.

[285] S. Rajeshkumar, L. V Bharath, and R. Geetha, Broad Spectrum Antibacterial Silver Nanoparticle Green Synthesis: Characterization, and Mechanism of Action, Elsevier Inc., Amsterdam, Netherlands, 2019.

[286] O. A. Dada, F. A. Adekola, and E. O. Odebunmi, "Kinetics and equilibrium models for sorption of $\mathrm{Cu}(\mathrm{II})$ onto a novel manganese nano-adsorbent," Journal of Dispersion Science and Technology, vol. 37, no. 1, pp. 119-133, 2016.

[287] A. O. Dada, F. A. Adekola, and E. O. Odebunmi, "A novel zerovalent manganese for removal of copper ions: synthesis, characterization and adsorption studies," Applied Water Science, vol. 7, no. 3, pp. 1409-1427, 2017.

[288] K. Koga and K. Sugawara, "Population statistics of gold nanoparticle morphologies: direct determination by HREM observations," Surface Science, vol. 529, no. 1-2, pp. 23-35, 2003.

[289] P. R. Somani, S. P. Somani, and M. Umeno, "Planer nanographenes from camphor by CVD," Chemical Physics Letters, vol. 430, no. 1-3, pp. 56-59, 2006.

[290] Z. Cai, Q. Yao, X. Chen, and X. Wang, Chapter 14: Nanomaterials with Different Dimensions for Electrocatalysis, Elsevier Inc., Amsterdam, Netherlands, 2019.

[291] H. Tanimoto, S. Ohmura, and Y. Maeda, "Size-selective formation of hexagonal silver nanoprisms in silver citrate solution by monochromatic-visible-light irradiation," The Journal of Physical Chemistry C, vol. 116, no. 29, pp. 15819-15825, 2012.

[292] S. Iravani, H. Korbekandi, and B. Zolfaghari, "Synthesis of silver nanoparticles: chemical, physical, and biological methods," Research in Pharmaceutical Sciences, vol. 9, no. 6, pp. 385-406, 2014. 
[293] A. O. Dada, A. A. Inyinbor, E. I. Idu et al., "Effect of operational parameters, characterization, and antibacterial studies of green synthesis of silver nanoparticles using Tithonia diversifolia," PeerJ, vol. 6, pp. e5865-17, 2018.

[294] J. Y. Song and B. S. Kim, "Rapid biological synthesis of silver nanoparticles using plant leaf extracts," Bioprocess and Biosystems Engineering, vol. 32, no. 1, pp. 79-84, 2009.

[295] A. Oluwasogo, F. A. Adekola, F. E. Dada et al., "Heliyon silver nanoparticle synthesis by Acalypha wilkesiana extract: phytochemical screening, characterization, influence of operational parameters, and preliminary antibacterial testing," Heliyon, vol. 5, Article ID e02517, 2019.

[296] M. A. Sabri, A. Umer, G. H. Awan, M. F. Hassan, and A. Hasnain, "Selection of suitable biological method for the synthesis of silver nanoparticles," Nanomaterials and Nanotechnology, vol. 6, no. 29, pp. 29-20, 2016.

[297] S. C. G. K. Daniel, V. Sureshkumar, and M. Sivakumar, "Nano-ice based on silver nanoparticles for fish preservation," International Journal of Fisheries and Aquatic Studies, vol. 4, no. 5, pp. 162-167, 2016.

[298] J. U. Chandirika, S. T. Selvi, and G. Annadurai, "Synthesis and characterization of silver nanoparticle using Melia azedarach for vegetable coating and antibacterial activity," Journal of Innovations in Pharmaceutical and Biological Sciences, vol. 5, pp. 38-42, 2018.

[299] S. Jebril, R. Khanfir Ben Jenana, and C. Dridi, "Green synthesis of silver nanoparticles using Melia azedarach leaf extract and their antifungal activities: in vitro and in vivo," Materials Chemistry and Physics, vol. 248, Article ID 122898, 2020.

[300] T. Rajkumar, A. Sapi, G. Das, T. Debnath, A. Ansari, and J. K. Patra, "Biosynthesis of silver nanoparticle using extract of Zea mays (corn flour) and investigation of its cytotoxicity effect and radical scavenging potential," Journal of Photochemistry and Photobiology B: Biology, vol. 193, pp. 1-7, 2019.

[301] A. A. Alfuraydi, S. Devanesan, M. Al-ansari, M. S. Alsalhi, and A. J. Ranjitsingh, "Eco-friendly green synthesis of silver nanoparticles from the sesame oil cake and its potential anticancer and antimicrobial activities," Journal of Photochemistry and Photobiology B: Biology, vol. 192, pp. 83-89, 2019.

[302] P. Das, K. Ghosal, N. K. Jana, A. Mukherjee, and P. Basak, "Green synthesis and characterization of silver nanoparticles using Belladonna Mother Tincture and its efficacy as a potential antibacterial and anti-inflammatory agent," $M a$ terials Chemistry and Physics, vol. 228, pp. 310-317, 2019.

[303] S. Menon, H. Agarwal, S. R. Kumar, and S. V. Kumar, "Green synthesis of silver nanoparticles using medicinal plant Acalypha indica leaf extracts and its application as an antioxidant and antimicrobial agent against foodborne pathogens," International Journal of Applied Pharmaceutics, vol. 9, no. 5, pp. 42-50, 2017.

[304] E. Parthiban, N. Manivannan, R. Ramanibai, and N. Mathivanan, "Green synthesis of silver nanoparticles from Annona reticulata leaves aqueous extract and its mosquito larvicidal and the antimicrobial activity on human pathogens," Biotechnology Reports, vol. 21, Article ID e00297, p. e00297, 2019.

[305] W. R. Rolim, M. T. Pelegrino, B. de Araújo Lima et al., "Green tea extract mediated biogenic synthesis of silver nanoparticles: characterization, cytotoxicity evaluation, and antibacterial activity," Applied Surface Science, vol. 463, pp. 66-74, 2019.
[306] K. M. Soto, C. T. Quezada-cervantes, M. Hernández-Iturriaga, G. Luna-Bárcenas, R. Vazquez-Duhalt, and S. Mendoza, "Fruit peels waste for the green synthesis of silver nanoparticles with antimicrobial activity against foodborne pathogens," LWT, vol. 103, pp. 293-300, 2019.

[307] N. G. Girón-Vázquez, C. M. Gómez-Gutiérrez, C. A. SotoRobles et al., "Study of the effect of Persea americana seed in the green synthesis of silver nanoparticles and their antimicrobial properties," Results in Physics, vol. 13, Article ID 102142, 2019.

[308] L. Azeez, A. Lateef, A. A. Wahab et al., "Phytomodulatory effects of silver nanoparticles on Corchorus olitorius: its antiphytopathogenic and hepatoprotective potentials," Plant Physiology and Biochemistry, vol. 136, pp. 109-117, 2019.

[309] D. Kalaiselvi, A. Mohankumar, G. Shanmugam, S. Nivitha, and P. Sundararaj, "Green synthesis of silver nanoparticles using latex extract of Euphorbia tirucalli: a novel approach for the management of root knot nematode, Meloidogyne incognita," Crop Protection, vol. 117, pp. 108-114, 2019.

[310] U. Suresh, K. Murugan, C. Panneerselvam et al., "Suaeda maritima-based herbal coils and green nanoparticles as potential biopesticides against the dengue vector Aedes aegypti and the tobacco cutworm Spodoptera litura," Physiological and Molecular Plant Pathology, vol. 101, pp. 225235, 2018.

[311] E.-Y. Ahn, H. Jin, and Y. Park, “Assessing the antioxidant, cytotoxic, apoptotic, and wound healing properties of silver nanoparticles green-synthesized by plant extracts," Materials Science and Engineering: C, vol. 101, pp. 204-216, 2019.

[312] T. Alves, J. De Souza, L. Rodrigues, R. Souza, and L. Pereira, "Ecotoxicology and environmental safety silver nanoparticles: an integrated view of green synthesis methods, transformation in the environment, and toxicity," Ecotoxicol. Environ. Saf., vol. 171, pp. 691-700, 2019. 